\title{
Disentangling the complex roles of markets on coral reefs in northwest Madagascar
}

\author{
$\underline{\text { Eva Maire }}^{1,2,3}$, Stephanie D'agata $^{4,5}$, Catherine Aliaume $^{1}$, David Mouillot $^{1,2}$, Emily S. Darling $^{6}$, Volanirina Ramahery ${ }^{4,7}, \underline{\text { Ravaka }}^{2}$ \\ $\underline{\text { Ranaivoson }}^{4}, \underline{\text { Bemahafaly Randriamanantsoa }}^{4}$, Tantely F. Tianarisoa $^{4}, \underline{\text { Abdoul Santisy }}^{4}$ and Joshua E. Cinner $^{2}$
}

\begin{abstract}
Rapid degradation of the world's coral reefs jeopardizes their ecological functioning and ultimately imperils the wellbeing of the millions of people with reef-dependent livelihoods. Ecosystem accessibility is the main driver of their conditions, with the most accessible ecosystems being most at risk of resource depletion. People's socioeconomic conditions can change as they get further from urban centers and can profoundly influence people's relationship with the environment. However, the mechanisms through which increasing accessibility from human societies affects natural resources are still unclear. A plausible mechanism through which markets influence the environment is through the socioeconomic changes that tend to accompany accessibility. We used social and ecological data from 10 coastal communities and 31 reefs in northwest Madagascar to (i) unravel the respective influences of the local fish market and coastal communities on reef fish biomass and (ii) investigate how communities' socioeconomic and resource use characteristics change with increasing proximity to markets. We used generalized additive models to reveal that reef fish biomass is strongly related to the accessibility of both markets and local communities. We also highlight that the ways coastal communities use marine resources changes predictably with market proximity. More precisely, market proximity affects fishing gear (technique effect), wealth, and selling strategies (scale effect) of coastal communities. Our findings emphasize the need to better quantify links between markets and fishing communities through household-level surveys to implement market-based actions that could help to regulate the effect of markets on both fish stocks and fishing communities.
\end{abstract}

Key Words: accessibility; coral reef fisheries; fish biomass; market access; social-ecological systems

\section{INTRODUCTION}

Earth's ecosystems are under increasing pressure as globalization connects the world (Liu et al. 2013). Expanding trade, transportation, migration, and technology are altering intertwined dynamics between human and natural ecosystems across space and time (Rockström et al. 2009, Liu et al. 2015). Global trade through interconnected markets or new access to markets can increase accessibility through road networks and infrastructure expansion, which in turn, profoundly shape the exploitation of both terrestrial and marine natural resources (Laurance et al. 2009, Dobson et al. 2010, Mora et al. 2011, Ahmed et al. 2014, Barber et al. 2014, Alamgir et al. 2017). There are growing concerns about the risk of unsustainable resources use due to unregulated trade in those previously isolated areas, with obvious ecological and management implications for those key ecosystems (Berkes et al. 2006, Rockström et al. 2009, Steffen et al. 2011, McCauley et al. 2013, Mora et al. 2016, Tregidgo et al. 2017).

However, research on the potential mechanisms through which increasing market accessibility influences ecological conditions is still nascent. To date, research on market accessibility has primarily examined how increased market access can affect resource users through the obvious mechanism of trade and price changes (Delgado et al. 2003, Schmitt and Kramer 2009, Thyresson et al. 2011, 2013, Januchowski-Hartley et al. 2020). Yet there are other potential mechanisms that have received less attention. Recent research has quantified how people's socioeconomic conditions, i.e., wealth, educational attainment, and health care utilization, change as they live further from urban centers (Weiss et al. 2018). Certain socioeconomic conditions, such as poverty or islandness, can profoundly influence people's relationship with the environment (Carter and Barrett 2006, Cinner 2011, Coulthard et al. 2017). Thus, a plausible mechanism through which markets influence the environment is through the socioeconomic changes that tend to accompany resource accessibility. As a heuristic to guide this type of exploration, a parallel literature on the impacts of economic development on the environment highlights three causal pathways: (i) a technique effect, whereby societies can use alternative technologies to conserve or exploit resources; (ii) a composition effect, which suggests that the structure of the local economy changes with economic transitions, for example, from a natural resource-based economy to a service-based economy, and (iii) a scale effect, which refers to the size of the economy where wealthier communities exploit more natural resources leading to increasing environmental degradation and potential displacement of exploitation further afield, often in places that are poorer or less regulated (Grossman and Krueger 1995, Cinner et al. 2009a, Lange et al. 2018).

Here, we focus on small-scale fisheries that are an essential source of food, culture, and livelihoods for millions of people around the world (Béné et al. 2007, Bell et al. 2009, Teh et al. 2013). Specifically, we consider artisanal coral reef fisheries of northwest Madagascar. We hypothesize that coral reef ecological conditions

\footnotetext{
${ }^{1}$ MARBEC, Univ. Montpellier, CNRS, Ifremer, IRD, Montpellier, France, ${ }^{2}$ Australian Research Council Centre of Excellence for Coral Reef Studies, James Cook University, Townsville, QLD Australia, ${ }^{3}$ Lancaster Environment Centre, Lancaster University, Lancaster, UK, ${ }^{4}$ Wildlife Conservation Society, Marine Conservation, Madagascar Program, ${ }^{5}$ Department of Earth and Environmental Sciences, Macquarie University, Sydney, NSW, Australia, ${ }^{6}$ Wildlife Conservation Society, Global Marine Program, Bronx, New York, USA, ${ }^{7}$ Nexus Madagascar Company, Toliara, Madagascar
} 
improve with decreasing accessibility to both markets and coastal communities, and that these relationships depend on the presence and effectiveness of fisheries management. We also evaluate how market access, i.e., the travelling time to the nearest market, affects community-level socioeconomic characteristics of resource use, e.g., fisheries dependence, livelihood diversity, or fishing gear technologies. Specifically, we aim to better understand the entwined relationships between local fish markets (hereafter "markets"), socioeconomic characteristics of coastal communities, and the ecological conditions of coral reefs (Cinner et al. 2009a, Tsurumi and Managi 2010, Sugiawan et al. 2017). The objectives of our study are to investigate (i) the relative effects of market access, fisheries management, and key environmental variables on reef fish biomass in the northwest of Madagascar; and (ii) the association between socioeconomic characteristics and markets among coastal communities. We address these questions using ecological data collected in 31 reefs, and socioeconomic information from household-level surveys conducted in 10 coastal communities in northwest Madagascar.

\section{Context and study area}

Madagascar relies heavily on the exploitation of natural resources for subsistence and livelihoods (World Bank 2010, Conservation International 2015). The artisanal fishery is a significant economic sector comprising multigear and multispecies fishing activities, where fishers can access reefs directly from the shore or using wooden pirogue canoes (McKenna and Allen 2003, Doukakis et al. 2008, Davies et al. 2009). Artisanal fisheries in Madagascar are vital to food security and livelihoods for coastal communities and support the majority of the Malagasy coastal population (Barnes-Mauthe et al. 2013). This is particularly true along the west coast where agricultural production remains low (FAO et al. 2018) and employment options are limited (Laroche and Ramananarivo 1995, Le Manach et al. 2012).

Coral reefs in northwest Madagascar are recognized for their exceptional biodiversity and their resilience to climate change in the Western Indian Ocean (McKenna and Allen 2003, McClanahan et al. 2011a, Obura 2012). The west coast of Madagascar is now considered as a high priority for increased management efforts as a potential "climate refugia" in the Western Indian Ocean (McClanahan et al. 2011b, Beyer et al. 2018). Coral reef management actions in Madagascar have mainly focused on strengthening local governance of marine resources that are socially acceptable and can deliver benefits for local economics and biodiversity (Harris 2011, Westerman and Gardner 2013). In rural communities, management actions are based on social conventions known as dinas (Rakotoson and Tanner 2006) aimed at increasing fish stocks and biodiversity, protecting cultural heritage, and promoting sustainable socioeconomic development to contribute to poverty reduction (Govan et al. 2009, Jupiter et al. 2014, Rocliffe et al. 2014). More specifically in northwest Madagascar, there are currently three forms of marine resource management: (i) marine protected areas (MPAs) managed by Madagascar National Parks; (ii) MPAs that are managed by local communities recognizing the dinas and with the technical and financial support of national or international associations or NGOs; and (iii) locally managed marine areas (LMMAs) managed by local communities based on a legal framework, the Gestion Locale Sécurisée (GELOSE), designed to integrate the dinas with governmental laws to enable community-based management of natural resources (Rakotoson and Tanner 2006). Within the MPAs and LMMAs in this area, management typically includes restricted zones where fishing is allowed using certain types of gear and access is restricted to local fishers, and permanent no-take reserves where all fishing activities are prohibited. In addition, beach seining, considered as a destructive fishing practice, has been historically prohibited along most coastal areas through dinas and is now nationally prohibited in Madagascar since 2018 (although is still happening in some areas without strong management structures). Shark fishing and sea cucumber harvesting are also regulated in the northwest, as are seasonal closures of some pelagic fisheries, e.g., Indian mackerel Rastrelliger kanagurta.

\section{METHODS}

\section{Study area}

Our study includes coral reefs along $\sim 150 \mathrm{~km}$ of coastline from Nosy Iranja to Nosy Mitsio (Fig. 1). The area is characterized by many small islands off the coast where human settlements are relatively sparse, consisting of dispersed small villages. Most of the fishing vessels are sailing wooden pirogue canoes and the most commonly employed gear are spear guns, gillnets, lines, fish traps (creels and valakira), and beach seines, despite recent legal regulations (Doukakis et al. 2008, Davies et al. 2009, Jadot et al. 2015). This area includes one national park (Nosy Tanikely), officially established in 2011, that encompasses an uninhabited island and surrounding waters where fishing is prohibited and two MPAs (Ankarea and Ankivonjy) that were officially established in April 2015 and are comanaged between local communities and the Wildlife Conservation Society. The two latter MPAs have designated restriction strategies by which local fishers have exclusive access rights to fishing inside each MPA. The management plans for each MPA are based on the existing dinas in both areas, and complemented by national policies on flagged species (shark, whales, sea turtles), habitats (mangroves, coral reefs), and gear restrictions, including bans on (i) beach seines, (ii) nets with mesh size under $25 \mathrm{~mm}$, (iii) nets over $500 \mathrm{~m}$ long, and (iv) any fishing gear directly entering in contact with the bottom to avoid coral reef destruction. Outside MPAs, only national restrictions apply but the level of compliance is generally poor (Westerman and Gardner 2013). Given the multiplicity of management forms in our study area, we categorized sites based on whether fishing is permitted (open access and restricted reefs) or fishing is prohibited (no-take zones within the two forms of management; Fig. 1). However, we recognize that levels of compliance within the "fishing prohibited" category may vary.

\section{Ecological surveys}

We surveyed 31 ecological sites (hereafter "reefs") between April and November 2016, comprising 16 reefs where fishing is permitted and 15 reefs where fishing is prohibited (Fig. 1). Surveys occurred on the main reef types in our study areas, including both fringing reefs of continental islands and complex patch reefs. For each reef, transects were performed on the slope and oriented parallel to the depth contour between 3 and $14 \mathrm{~m}$.

\section{Reef fish survey}

Distance-sampling underwater visual census (D-UVC) was used to survey finfishes along $50 \mathrm{~m}$ long transects. This method involved two divers, where each diver recorded the species, 
abundance, body length, and distance perpendicular to the transect line of each fish or group of fish, while swimming slowly down the line (Labrosse et al. 2002). We included 25 fish families that represent the main reef fish families in the study region (Acanthuridae, Balistidae, Caesionidae, Carangidae, Chaetodontidae, Ephippidae, Fistularidae, Haemulidae, Holocentridae, Kyphosidae, Labridae, Lethrinidae, Lutjanidae, Mullidae, Nemipteridae, Pempheridae, Pomacanthidae, Pomacentridae, Scaridae, Scombridae, Scorpaenidae, Serranidae, Siganidae, Sphyraenidae, and Zanclidae). Transects width were truncated at $5 \mathrm{~m}$ on each side allowing for species density estimation on a $500 \mathrm{~m}^{2}$ transect $(50 \mathrm{x}$ $10 \mathrm{~m}$ ). The biomass of individual fish was estimated using the allometric length-weight conversion: $\mathrm{W}=\mathrm{aTL} \mathrm{L}^{\mathrm{b}}$, where parameters $\mathrm{a}$ and $\mathrm{b}$ are species-specific constants extracted from FishBase (), TL is the individual total fork length in centimeters, and $\mathrm{W}$ is the weight in grams (Kulbicki et al. 2005). Biomass of each transect was further converted to kilograms per hectare of reef area.

Fig. 1. Map of the study area located off the southeast coast of Africa in northwest Madagascar. Surveyed reefs where fishing is permitted (open access and restricted reefs: orange squares) or fishing is prohibited (no-take zones within the two forms of management: green squares), coastal communities (circles), local markets (stars), and cartography of reefs (blue shades) are represented. Each coastal community is colored according to its nearest market (Ambilobe: black; Ambanja: white, Hell Ville: grey).

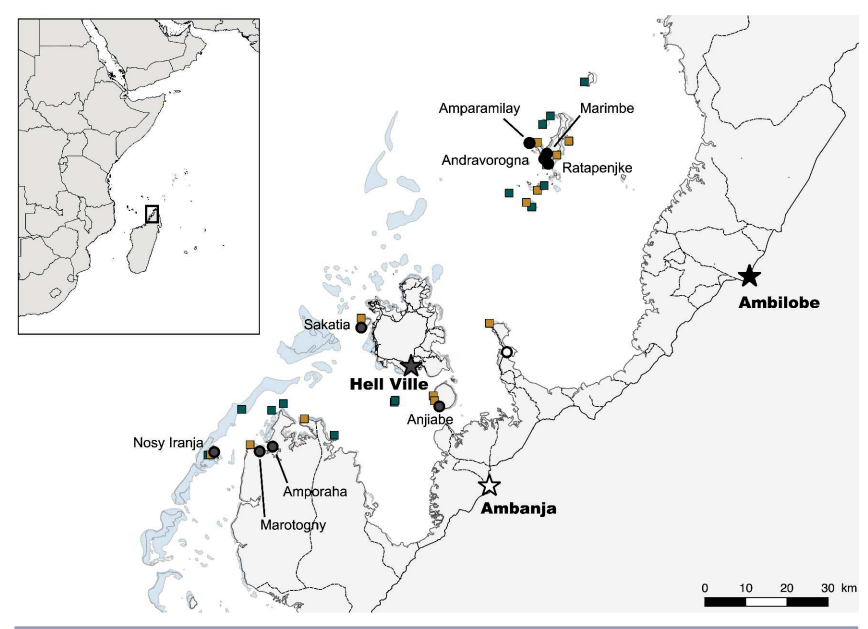

Reef habitat and environmental variables

Point intercept transects (Hill and Wilkinson 2004) were used to assess benthic conditions. This method consists of recording the benthic substrate at $25-\mathrm{cm}$ intervals along a $50-\mathrm{m}$ transect. We estimated the percent cover of live hard coral and macroalgae as major benthic covariates of interest. We also visually measured structural macro-complexity, which was estimated every 5 to 10 $m$ along each transect to provide an average structural complexity score per transect. Scores ranged from 0 (no vertical relief, flat, or rubbly areas) to 5 (Wilson et al. 2007). The mean depth over each transect was also recorded during surveys.

To evaluate the environmental conditions on each reef, weekly average sea surface temperature (SST) and chlorophyll-a concentration, which provide information on the amount of primary production occurring in the ocean (Huot et al. 2007), were extracted during a 5-year period (2012-2016) at a 4-km resolution from the Geostationary Operational Environmental Satellites and the Polar-orbiting Operational Environmental Satellites (GOES-POES) dataset and the Moderate Resolution Imaging Spectro-radiometer (MODIS; http://oceanwatch.pifsc. noaa.gov/). For each reef, we calculated the weekly average of temperature and ocean primary productivity over a 5-year period (2012-2016) but we did not account for seasonality.

Using a set of six reef habitat and environmental variables, we first performed a principal components analysis (PCA) to describe similarities between our ecological sites while dealing with multicollinearity and we included depth, weekly average SST and primary productivity, reef complexity, percent cover of macroalgae, and live hard coral (Cinner et al. 2013, Maire et al. 2016, McClanahan et al. 2016). We only retained the first two components (representing $56 \%$ of the total variance; see Appendix 1) that mix abiotic and benthic conditions as environmental covariates for further analysis.

\section{Travel time to markets}

For each reef, we considered two human settlements: (i) the nearest coastal community; and (ii) the nearest market. Travel time was estimated as the shortest time of travelling between each reef and its nearest market and community, respectively, considering the following:

- Sea travel using wooden pirogue canoes: speed of $7 \mathrm{~km} \cdot \mathrm{h}^{-1}$

- Primary roads using motorized vehicles: speed of $50 \mathrm{~km}$. $\mathrm{h}^{-1}$

- Track/secondary roads using motorized vehicles: speed of $20 \mathrm{~km} \cdot \mathrm{h}^{-1}$

Speed values were estimated from field observation in MarchApril 2016, road network data was extracted from the OpenStreetMap (OSM) project and was completed by GPS tracks obtained during field campaigns in March-April 2016.

We also assessed the total human population occurring within a 4- $\mathrm{km}$ radius of each reef using the WorldPop dataset version 2.0 (Tatem 2017), which estimates human population with national adjustments at a 100-m resolution for the year 2015 (the year closest to 2016, year in which the ecological and social surveys were conducted). We set the cut-off at $4 \mathrm{~km}$ to reduce spatial overlap between reefs. All social and environmental variables considered in the study and expected to influence reef fish biomass are described in Table 1.

\section{Socioeconomic surveys}

Semistructured questionnaires were conducted at 10 coastal communities (Fig. 1) to collect information on socioeconomic characteristics, fishing and farming activities, resource use, and management. Surveys were conducted across three districts in northwest Madagascar from November to December 2016 by trained and experienced Malagasy interviewers (Fig. 1, Appendix 2). For communities with less than 50 households, all households were surveyed; in larger communities, 50 households were randomly chosen when possible. In total, 354 household surveys were conducted across the 10 communities (Appendix 2). All survey activities were approved by the Wildlife Conservation 
Table 1. Name and description of human, environmental, and habitat variables considered to influence total reef fish biomass. References and statistical transformation are also described for each variable.

\begin{tabular}{|c|c|c|c|c|}
\hline Category & Name & Description & References & Transformation \\
\hline Human & Human population size & $\begin{array}{l}\text { Number of inhabitants in a } 4-\mathrm{km} \text { buffer } \\
\text { around the reef extracted from WorldPop } \\
100 \text {-m resolution dataset version } 2.0\end{array}$ & $\begin{array}{l}\text { Mora et al. 2011, Brewer et } \\
\text { al. } 2012\end{array}$ & $\begin{array}{l}\text { Log transformed and } \\
\text { standardized }\end{array}$ \\
\hline Human & $\begin{array}{l}\text { Travel time from the nearest } \\
\text { market }\end{array}$ & $\begin{array}{l}\text { Travel time between each reef and the } \\
\text { nearest market }\end{array}$ & $\begin{array}{l}\text { Brewer et al. 2012, Cinner et } \\
\text { al. 2013, D'Agata et al. 2016, } \\
\text { Maire et al. } 2016\end{array}$ & Standardized \\
\hline Human & $\begin{array}{l}\text { Travel time from the nearest } \\
\text { community }\end{array}$ & $\begin{array}{l}\text { Travel time between each reef and the } \\
\text { nearest coastal community }\end{array}$ & & Standardized \\
\hline Human & Management type & $\begin{array}{l}\text { Whether fishing is permitted or } \\
\text { prohibited }\end{array}$ & $\begin{array}{l}\text { McClanahan et al. 2016, } \\
\text { Cinner et al. } 2018\end{array}$ & I \\
\hline Environment & $\begin{array}{l}\text { Sea surface temperature } \\
\text { (SST) }\end{array}$ & $\begin{array}{l}\text { Weekly average SST over 2012-2016 } \\
\text { extracted from GOES-POES 4-km } \\
\text { resolution dataset }\end{array}$ & Williams et al. 2015 & $\begin{array}{l}\text { Reduced as two PCA } \\
\text { components and standardized }\end{array}$ \\
\hline Environment & Primary productivity & $\begin{array}{l}\text { Weekly average chlorophyll-a } \\
\text { concentration over 2012-2016 extracted } \\
\text { from MODIS-Aqua 4-km resolution } \\
\text { dataset }\end{array}$ & Williams et al. 2015 & $\begin{array}{l}\text { Reduced as two PCA } \\
\text { components and standardized }\end{array}$ \\
\hline Habitat & Depth & Mean depth along the $50-\mathrm{m}$ transect & $\begin{array}{l}\text { Srinivasan 2003, Brokovich } \\
\text { et al. } 2008\end{array}$ & $\begin{array}{l}\text { Reduced as two PCA } \\
\text { components and standardized }\end{array}$ \\
\hline Habitat & $\%$ Live hard coral & $\begin{array}{l}\text { Sum of the percentage of the } \\
\text { corresponding category within the } 200 \\
\text { points along the } 50 \text {-m transect. Estimated } \\
\text { during ecological surveys and following } \\
\text { the Point Intercept Transect } 25-\mathrm{cm} \\
\text { (PIT25) procedure described by Hill and } \\
\text { Wilkinson (2004). }\end{array}$ & $\begin{array}{l}\text { Luckhurst and Luckhurst } \\
\text { 1978, Roberts and Ormond } \\
\text { 1987, Bellwood et al. 2004, } \\
\text { Norström et al. 2009, Stella } \\
\text { et al. } 2011\end{array}$ & $\begin{array}{l}\text { Reduced as two PCA } \\
\text { components and standardized }\end{array}$ \\
\hline Habitat & $\%$ Macro algae & & & $\begin{array}{l}\text { Reduced as two PCA } \\
\text { components and standardized }\end{array}$ \\
\hline Habitat & Reef complexity & $\begin{array}{l}\text { Score from } 0 \text { (no vertical relief, flat, or } \\
\text { rubbly areas) to } 5 \text { (exceptionally complex } \\
\text { relief with numerous caves and over } \\
\text { hangs) along the } 50-\mathrm{m} \text { transect. Estimated } \\
\text { during ecological surveys and adapted } \\
\text { from Wislon et al. (2007) }\end{array}$ & $\begin{array}{l}\text { McCormick 1994, Nash et } \\
\text { al. 2013, Ferrari et al. } 2016\end{array}$ & $\begin{array}{l}\text { Reduced as two PCA } \\
\text { components and standardized }\end{array}$ \\
\hline
\end{tabular}

Society Institutional Review Board as part of a global socialecological monitoring framework designed to monitor the impact of conservation and management interventions (Gurney and Darling 2017).

We adapted indicators of the technique, composition, and scale effects to the fishery of northwest Madagascar (Table 2). As indicators of the technique effect, we examined fishing gear use (Brewer 2013, Stevens et al. 2014) by considering gear diversity and the nature of the main gear (spear, line, and gill net) used by households. As an indicator of the composition effect, we examined livelihood diversification (number of livelihood activities; Cinner and Bodin 2010, Chaves et al. 2017, Kramer et al. 2017) with a focus on fishing activity (proportion of households who rank fishing as primary activity). As indicators of the scale effect, we examined both fish demand and displacement of environmental footprints. More precisely, fish demand was analyzed through the wealth of coastal communities using a material style of life index (Pollnac and Crawford 2000) and fish consumption. Displacement of environmental footprints was assessed through the proportion and the degree to which people sold their catch, either directly to local markets or to middlemen who sold fish outside the village. For all indicators, we calculated an average community-level mean to use in our analyses (see details in Table 2).

\section{Data analysis}

To explore how proximity to markets and communities affect reef fish biomass beyond ecological and human population size effects, we built generalized additive models (GAMs) considering the two environmental covariates provided by PCA, human population size, travel time from human settlements and markets, and management. All covariates were standardized before modeling (Table 1). GAMs have the property of exploring nonlinear relationships using smooth functions, thus there is no need to make any a priori assumption on the shape of the relationship (Hastie and Tibshirani 1990). All terms used a reasonable spline smoothed function $(\mathrm{k}=3)$ given the limited number of data. We considered all the possible submodels, i.e., all the possible combination of variables, including travel time from the nearest market and the nearest community, and management type (fishing permitted or prohibited). We also considered interactions between management and market or community. Because all these models are nested, we performed a likelihood ratio test (LRT) to determine which human variables significantly improved model fit (Wood 2006). We also assessed model fitting and parsimony by using AICc, Akaike Information Criterion corrected for small data samples (Hurvich and Tsai 1989). Prior to modeling, biomass response variable was $\log +1$ transformed. We also checked for collinearity among our covariates using bivariate correlations (all coefficients were $<0.7$ ) 
Table 2. Description of the 10 indicators measured for the 10 coastal communities to investigate the association between socioeconomic characteristics and markets among coastal communities. Markets can affect communities through three causal pathways: (i) a technique effect, (ii) a composition effect, and (iii) a scale effect. Theory and references for each effect are also described.

\begin{tabular}{|c|c|c|c|c|c|c|}
\hline Market mechanism & Theory & References & Indicator & Description & Survey method & $\begin{array}{l}\text { Sample } \\
\text { size }\end{array}$ \\
\hline \multirow[t]{4}{*}{ Technique effect } & $\begin{array}{l}\text { New or altered technologies are } \\
\text { more likely to occur near } \\
\text { markets resulting in higher gear } \\
\text { diversity and changes in fishing } \\
\text { practices }\end{array}$ & $\begin{array}{l}\text { Brewer 2013, } \\
\text { Stevens et al. } 2014\end{array}$ & Gear diversity & $\begin{array}{l}\text { The mean number of gear } \\
\text { types that household used }\end{array}$ & Fishers only & 164 \\
\hline & & & Spear & $\begin{array}{l}\% \text { of households who ranked } \\
\text { spear as main gear }\end{array}$ & Fishers only & 164 \\
\hline & & & Line & $\begin{array}{l}\% \text { of households who ranked } \\
\text { line as main gear }\end{array}$ & Fishers only & 164 \\
\hline & & & Gill net & $\begin{array}{l}\% \text { of households who ranked } \\
\text { gill net as main gear }\end{array}$ & Fishers only & 164 \\
\hline \multirow[t]{2}{*}{ Composition effect } & $\begin{array}{l}\text { Households near markets may } \\
\text { be involved in more activities } \\
\text { and have reduced dependence } \\
\text { on fishing }\end{array}$ & $\begin{array}{l}\text { Cinner and Bodin } \\
\text { 2010, Charlton et } \\
\text { al. 2016, Chaves et } \\
\text { al. 2017, Kramer et } \\
\text { al. } 2017\end{array}$ & $\begin{array}{l}\text { Livelihood } \\
\text { diversity }\end{array}$ & $\begin{array}{l}\text { The mean number of } \\
\text { livelihood activities that } \\
\text { households are involved in }\end{array}$ & $\begin{array}{l}\text { All households } \\
\text { surveys }\end{array}$ & 353 \\
\hline & & & Fishing activity & $\begin{array}{l}\% \text { of households who ranked } \\
\text { fishing as primary activity }\end{array}$ & $\begin{array}{l}\text { All households } \\
\text { surveys }\end{array}$ & 353 \\
\hline \multirow[t]{4}{*}{ Scale effect } & $\begin{array}{l}\text { Demand: Relatively wealthier } \\
\text { communities may be located } \\
\text { closer to markets and may have } \\
\text { increased demand for fish }\end{array}$ & $\begin{array}{l}\text { Grossman and } \\
\text { Krueger 1995, } \\
\text { Cinner et al. 2009a, } \\
\text { Lange et al. } 2018\end{array}$ & $\begin{array}{l}\text { Material Style of } \\
\text { Life (MSL) }\end{array}$ & $\begin{array}{l}\text { A composite measure of } \\
\text { wealth based on household } \\
\text { possessions }\end{array}$ & $\begin{array}{l}\text { All households } \\
\text { surveys }\end{array}$ & 353 \\
\hline & & & Fish consumption & $\begin{array}{l}\text { the proportion of households } \\
\text { consuming fish at least once a } \\
\text { day }\end{array}$ & $\begin{array}{l}\text { All households } \\
\text { surveys }\end{array}$ & 353 \\
\hline & $\begin{array}{l}\text { Displacement: Economic } \\
\text { opportunities increase near } \\
\text { markets and may affect the way } \\
\text { fish are sold }\end{array}$ & $\begin{array}{l}\text { Grossman and } \\
\text { Krueger 1995, } \\
\text { Cinner et al. 2009a }\end{array}$ & Fish sold & $\begin{array}{l}\% \text { of fish catch sold to other } \\
\text { people }\end{array}$ & Fishers only & 164 \\
\hline & & & Selling strategy & $\begin{array}{l}\text { (i) Other people in the village, } \\
\text { (ii) fish trader/middleman } \\
\text { selling outside the village, (iii) } \\
\text { local market }\end{array}$ & Key informants & 20 \\
\hline
\end{tabular}

and the variance inflation factor (VIF) estimates (VIF $<5$ ). We then performed control procedure to check whether the smoothness selection criterion $(\mathrm{k}=3)$ was appropriate and detected outliers (Wood 2006). We lastly examined homoscedasticity and normality of residuals.

To explore the social characteristics of communities and mechanisms of technique, composition, and scale, we performed a PCA to explore correlations between the 10 social characteristics of coastal communities (Table 2) and travel time from the nearest market. Because the distance of community from a market was confounded with the presence of management (i.e., remote communities further away from markets were located within MPAs, whereas communities closer to markets were not associated with fisheries management), we included one supplementary variable to take into account the increased presence of management further away from markets. We checked the loadings of variables to identify which variables have the largest effect on each component and the score of each coastal community to quantify how communities are described by different components.

\section{RESULTS}

\section{Influence of travel time and management on fish biomass}

Among all the models tested, the best model (LRT's $p$-value = 0.02 and lowest AICc $=14.9)$ explained up to $83 \%\left(\right.$ adjusted $\left.R^{2}\right)$ of the variability observed in log fish biomass (Table 3 and Appendix 3). This model integrated travel time from community in interaction with management, as well as the effect of travel time from the nearest market (Table 3). Accessibility from human settlements (nearest market $\mathrm{p}$-value $=0.001$ and community $\mathrm{p}$ value $=0.04)$, local human population size $(\mathrm{p}$-value $=0.003)$, and management $(\mathrm{p}$-value $=0.003)$ were the most important predictors while only one environmental covariate (Env2 p-value $=0.02$ ) was important (Table 3). We found that log human population size had a significant negative influence on fish biomass in both reef categories, i.e., fishing permitted and fishing prohibited, at the same rate (Fig. 2c) while biomass increased further away from market until reaching a maximum at approximately 6-7 $\mathrm{h}$ from a market (Fig. 2b, Table 3 ). In the same vein, fish biomass increased nonlinearly with increasing travel time from the nearest community in reefs where fishing is permitted, with a sharp increase at approximately 1.5 hours (Fig. 2a). Conversely, fish biomass showed no relationship with travel 
Table 3. Significance table of all covariates included in the best-fit model of fish biomass $\left(\mathrm{R}^{2}\right.$ adj $\left.=0.83\right)$. The two first components (Env1 and Env2) of the principal component analysis (PCA) performed with habitat and environmental variables, human population size, travel time from the nearest market, and travel time from community in interaction with management (fishing permitted vs fishing prohibited) provided the best-fit model. Estimates and standard errors (SE) of estimates of fixed terms while estimated degree of freedom (edf) of smooth terms are provided with corresponding significance test.

\begin{tabular}{|c|c|c|c|c|c|}
\hline & Variable & Estimate & $\mathrm{SE}$ & $\mathrm{t}$ & $\operatorname{Pr}(>|t|)$ \\
\hline \multirow[t]{11}{*}{$\mathrm{R}^{2}(\operatorname{adj})=0.83$} & Fixed terms & & & & \\
\hline & Intercept & 2.58 & 0.077 & 33.7 & $<2 \mathrm{e}-16$ \\
\hline & Management (Fishing banned) & 0.41 & 0.12 & 3.41 & 0.003 \\
\hline & Smoothed terms $(\mathrm{k}=3)$ & edf & & $\mathrm{F}$ & $\mathrm{p}$-value \\
\hline & Env1 & 1.00 & & 0.89 & 0.4 \\
\hline & Env2 & 1.00 & & 6.73 & 0.02 \\
\hline & Population & 1.00 & & 11.1 & 0.003 \\
\hline & Travel time market & 1.82 & & 10.4 & 0.001 \\
\hline & Travel time village & 0.67 & & 6.63 & 0.04 \\
\hline & $\begin{array}{l}\text { Travel time village : Management } \\
\text { (Fishing allowed) }\end{array}$ & 1.50 & & 1.97 & 0.1 \\
\hline & $\begin{array}{l}\text { Travel time village : Management } \\
\text { (Fishing banned) }\end{array}$ & 0.83 & & 6.54 & 0.02 \\
\hline
\end{tabular}

Fig. 2. Partial effects of each socioeconomic covariate predicting log fish biomass in the model while considering the other predictor variables are held constant. Relationships between fish biomass and travel time from the nearest community (a), travel time from the nearest market (b), human population size (c), and management (d) for reefs where fishing is permitted (orange) or fishing is prohibited (green).
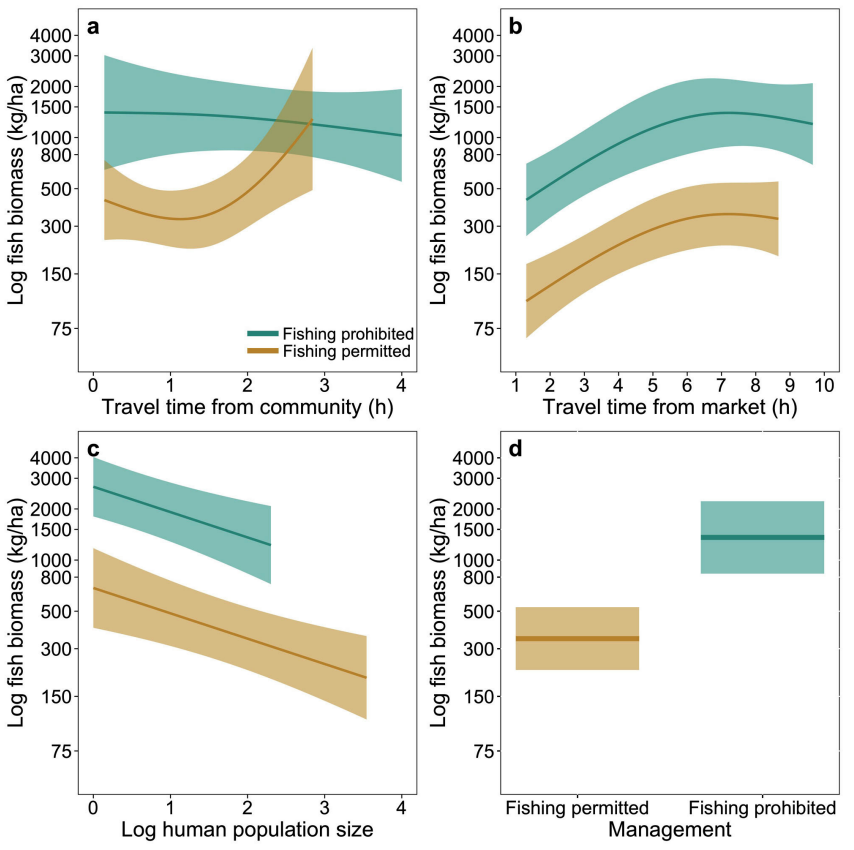

time from the nearest community in reefs where fishing is prohibited (Fig. 2a, Table 3).

Overall, reefs where fishing is permitted and located near markets and communities had lower reef fish biomass than their counterparts in no-take zones (Fig. 2b-d), demonstrating that marine reserves exert effective controls of fishing pressure in northwest Madagascar. It also suggests some local benchmarks for reef fish biomass can be attained in the absence of fishing at 1235 kg.ha ${ }^{-1}$ (Fig. 2d). Fish biomass in reefs where fishing is permitted increased beyond one-hour travel time to reach comparable level of biomass than reefs where fishing is prohibited at more than 2.5 hours from the community (Fig. 2a).

\section{Socioeconomic characteristics of coastal communities}

We found that $46 \%$ (range: $24-67 \%$ ) of households ranked fishing as their primary livelihood activity (Table 4), and that households were associated with two livelihoods activities on average (range at community level: 1.6-2.3; range of household responses: 1-4). Indicators of the technique effect showed that more than one-half of fishing households ( 96 out of 164 so $58 \%$ ) relied on only one gear type for their fishing activities (mean at community level: 1.5; range of household responses: 1-4). However, we highlighted a diversity of fishing practices where line fishing is the main gear type for $\sim 48 \%$ of households included in this survey (range across communities: $3-86 \%$ ), while $25 \%$ of households reported gill net as a primary gear (range across communities: $0-87 \%$ ) and $11 \%$ of households reported spear gun as the primary gear (range across communities: $0-37 \%$ of households).

We also examined fish demand and displacement of environmental footprints as indicators of the scale effect. We found that $51 \%$ of households consumed fish at least once a day (range at the community level: $38-65 \%$ ) while the material style of life (MSL), measuring the possessions of households, i.e., housing materials and electricity, showed two distinct subgroups because three communities had high MSL, i.e., wealthier communities, while seven communities had less assets (Table 4). Overall, all communities sold $\sim 85 \%$ of their catch (range: $71-$ $93 \%$ ). Although the 10 communities sold fish to other people in the village, key informants reported that seven communities regularly sold fish to middlemen, two sold to both local markets and middlemen, and only one sold fish exclusively within the community (Table 4). 
Table 4. Descriptive statistics of the socioeconomic indicators measured for the 10 coastal communities. Travel time from the nearest market and the presence of management actions are also provided.

\begin{tabular}{|c|c|c|c|c|c|c|c|c|c|c|c|c|}
\hline \multirow[b]{2}{*}{$\begin{array}{l}\text { Coastal } \\
\text { community }\end{array}$} & \multicolumn{2}{|c|}{ Composition effect } & \multicolumn{4}{|c|}{ Technique effect } & \multicolumn{4}{|c|}{ Scale effect } & \multirow[b]{2}{*}{$\begin{array}{l}\text { Travel } \\
\text { time from } \\
\text { market } \\
\text { (h) }\end{array}$} & \multirow[b]{2}{*}{ Management } \\
\hline & $\begin{array}{c}\text { \% of hh } \\
\text { engaged } \\
\text { in fishing } \\
\text { activities }\end{array}$ & $\begin{array}{c}\text { Mean } \\
\text { number } \\
\text { of } \\
\text { livelihoods }\end{array}$ & $\begin{array}{c}\text { Mean } \\
\text { gear } \\
\text { diversity }\end{array}$ & $\begin{array}{l}\text { \% using } \\
\text { gill net as } \\
\text { main } \\
\text { gear }\end{array}$ & $\begin{array}{c}\% \text { using } \\
\text { spear as } \\
\text { main } \\
\text { gear }\end{array}$ & $\begin{array}{c}\% \text { using } \\
\text { line as } \\
\text { main } \\
\text { gear }\end{array}$ & $\begin{array}{c}\text { Material } \\
\text { style of } \\
\text { life } \\
(\mathrm{MSL})\end{array}$ & $\begin{array}{l}\% \text { of hh } \\
\text { consuming } \\
\text { fish daily }\end{array}$ & $\begin{array}{c}\% \text { of fish } \\
\text { catches } \\
\text { sold }\end{array}$ & $\begin{array}{c}\text { Middle- } \\
\text { men } \dagger\end{array}$ & & \\
\hline Amparamilay & 66.7 & 2.3 & 1.3 & 0 & 37.5 & 50.0 & -0.07 & 60.0 & 92.1 & II & 7.8 & Ankarea MPA \\
\hline Andravorogna & 61.1 & 1.9 & 1.6 & 0 & 18.2 & 54.5 & -0.12 & 50.0 & 92.5 & II & 6.4 & Ankarea MPA \\
\hline Marimbe & 40.0 & 1.9 & 1.5 & 36.4 & 9.1 & 36.4 & -0.08 & 64.0 & 81.2 & I & 8.5 & Ankarea MPA \\
\hline Ratapenjke & 52.9 & 2.0 & 2.1 & 0 & 7.1 & 85.7 & -0.06 & 38.2 & 90.3 & II & 6.4 & Ankarea MPA \\
\hline Amporaha & 42.4 & 1.8 & 1.4 & 35.3 & 5.9 & 58.8 & -0.09 & 48.5 & 89.3 & II & 6.7 & Ankivonjy MPA \\
\hline Marotogny & 50.0 & 1.8 & 1.5 & 11.8 & 11.8 & 41.2 & -0.06 & 65.0 & 90.1 & II & 6.7 & Ankivonjy MPA \\
\hline Nosy Iranja & 25.6 & 1.6 & 1.3 & 11.1 & 0 & 55.6 & -0.09 & 51.3 & 70.9 & 0 & 7.9 & Ankivonjy MPA \\
\hline Anjiabe & 34.0 & 2.0 & 1.3 & 62.5 & 8.3 & 25.0 & 0.02 & 42.0 & 78.6 & II & 1.9 & open-access \\
\hline Antafiambotry & 62.0 & 1.6 & 1.6 & 86.7 & 0 & 3.3 & 0.01 & 50.0 & 92.4 & I & 1.9 & open-access \\
\hline Sakatia & 24.5 & 2.1 & 1.3 & 8.7 & 8.7 & 69.6 & 0.03 & 42.9 & 77.5 & II & 0.8 & open-access \\
\hline
\end{tabular}

$\dot{\dagger}(\mathrm{I})$ if first buyer, (II) if not first buyer and $(0)$ if absent

\section{Association between market proximity and community characteristics}

We also investigated whether proximity to market is related to communities' socioeconomic and resource use characteristics. Correlations from PCA showed that increasing travel time from the nearest market was associated with the following: fewer material assets (communities with lower MSL scores); higher fish consumption (scale effect); more spear and line fishing and less gill net fishing (technique effect); and increasing management (Fig. 3a, Appendix 4). We found that market access did not have a strong effect on the economic structure of households (composition effect) as the proportion of households engaged in fishing and livelihood diversity did not vary much across the communities, i.e., all communities were highly dependent on fishing livelihoods (Fig. 3a, Appendix 4). Finally, there was no significant association between gear diversity (technique effect) and market access (Fig. 3a, Appendix 4).

All communities sold a high proportion of their catches, and there was not a clear relationship between the proportion of fish catch sold and accessibility to markets (Table 4). Although greater travel time from the nearest market was not strongly associated with middleman as a preferred buyer, selling strategies were associated with market proximity (scale effect) (Fig. 3, Appendix 4). We found that fishing households from distant communities (up to two hours from market) did not reach the nearby market to sell fish catches but sold preferentially to their own community or to middlemen who occasionally collected seafood products in those remote communities (Fig. 3b). Similarly, a low proportion of fishing households (in two coastal communities) sold their catch directly to market only if their community was located at less than two hours (Fig. 3b). Overall, middlemen's influence was widespread in the region since they collected seafood products from very close (at less than two hours) but also to more distant communities from markets (up to eight hours) (Fig. 3b, Table 4).

Overall, six communities were properly represented $(\cos 2>0.4)$ by the first two components (PC1 and PC2) of the PCA (Fig. 3, Appendix 5). Surprisingly, we found that communities tended to be distributed through space according to the market (Hell Ville, Ambanja, or Ambilobe) they were nearest to (Fig. 3). Thus, not only travel time from the nearest market but also differences between markets could affect the communities' socioeconomic characteristics (Fig. 3a).

\section{DISCUSSION}

Our study shows how the accessibility of markets and local communities can affect both reef fish biomass and the socioeconomic characteristics of coastal communities. Our analysis also reveals interesting nonlinear patterns between accessibility and fish biomass. We found that fish biomass increases as reefs are further away from the market in both reef categories, i.e., fishing permitted and fishing prohibited (Fig. 2b), but that this effect levels off at about six hours from markets. Alternatively, we found that reefs where fishing is permitted remained relatively depleted when they were $<1.5$ hours from the nearest community, but biomass began to increase after 1.5 hours (Fig. 2a). Our results are broadly consistent with previous studies conducted at larger scales, i.e., national and global, highlighting that market integration is a major driver of fish biomass (Brewer et al. 2012, Cinner et al. 2013, D'Agata et al. 2016, Maire et al. 2016). However, the mechanisms associated with this market effect remain poorly understood.

To examine potential explanations for these relationships, we investigated how the socioeconomic and resource use characteristics of coastal communities change with proximity to markets through three strategies: (i) the change in techniques people used to harvest fish (called the technique effect); (ii) the composition of the economy (called the composition effect); and (iii) the scale at which people act as a consequence of economic growth (called the scale effect). Our findings suggest that market proximity in northwest Madagascar can affect coastal communities mainly through the technique and the scale effects, and that these effects could vary according to the characteristics of the nearest market.

First, we found that market proximity influenced the fishing techniques used by coastal households. In small-scale fisheries, gear diversity is generally high and increases over time as the number of fishers increases and economic development is more likely to bring new technologies or new materials that increase 
Fig. 3. Associations between market proximity and (a) socioeconomic characteristics of communities through a principal components analysis and (b) selling strategies. (a) Ten socioeconomic indicators were assessed for each of the 10 coastal communities: the mean number of gear types (Gear div.), the proportion of fishing households who ranked gill nets (Gill net), spear (Spear), and line (Line) as main gear, the proportion of households who ranked fishing as primary activity (Fishing), the mean number of livelihood activities that households are involved in (Livelihood div.), a composite index of community wealth (MSL), the proportion of households consuming fish at least once a day (Fish consumption), the proportion of fish sold (Fish sold), and the importance of middlemen (Middlemen) in fish selling that were related to market access (Travel time from market). Social indicators were associated with the composition (green), the technique (orange), or the scale (purple) effect. Because market accessibility and management actions had confounding effects in the study area (marine reserves are disproportionately located far from markets) we included one supplementary variable (Management) to take into account this effect. The 10 coastal communities are represented as colored dots according to which nearest market they are associated with (Ambilobe: black; Ambanja: white; Hell Ville: grey) and are in bold when the community is well represented by the first two components (Cos2 > 0.4, see Appendix 5). Most variables were properly represented (in bold) by the two first components except fish consumption, livelihood, and gear diversity (see Appendix 5). (b) When fish sold, we also looked at the relationship between the preferred buyer: own community, middlemen from other communities, or local market and market access. At least part of fish catch was sold directly within the community, but fish was also sold to middlemen or at the local market. Middlemen were widespread in the region and seemed to buy seafood products from very close ( $<2$ hours) to more distant communities from markets (up to 8 hours). Distributions are represented using $95 \%$ confidence intervals when possible.

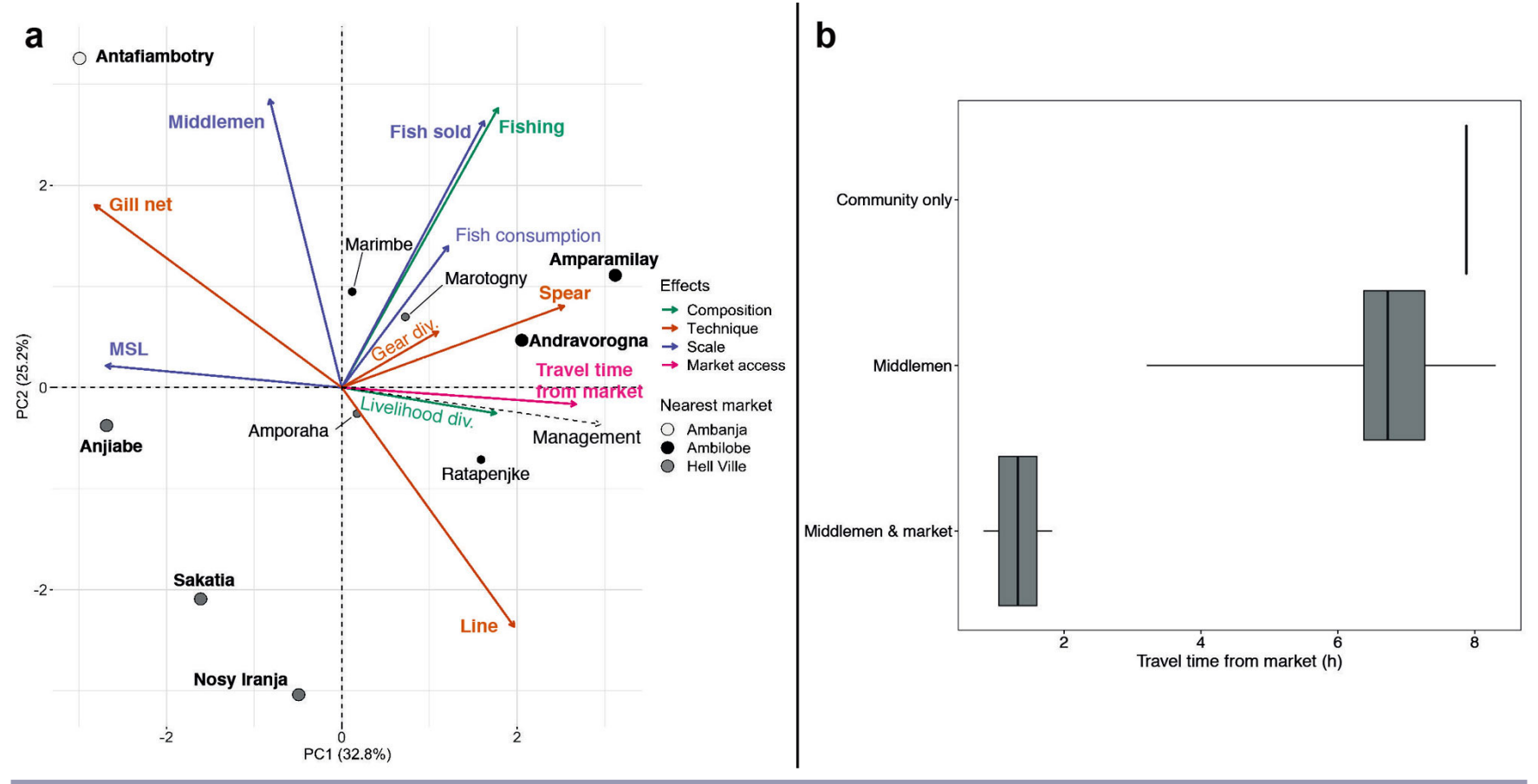

gear longevity (Brewer 2013, Teh et al. 2013, Stevens et al. 2014, Selgrath et al. 2018). In northwest Madagascar, more than onehalf of fishing households ( 96 out of 164 , or $58 \%$ ) only use one gear type while the maximum gear diversity is four, which is consistent with previous results from the Philippines showing that most artisanal fishers rely on only a few gear types (Selgrath et al. 2018). Although there is a confounding effect between gear restrictions (beach seines, mesh size $<25 \mathrm{~mm}$, and nets $>500-\mathrm{m}$ long) and market accessibility (MPAs with gear restrictions are located away from markets), we show that the use of spearfishing and, to a lesser extent, line fishing increase in poorer communities located in MPAs further away from markets while gill nets (mesh size $>$ and $<5 \mathrm{~mm}$ ) were dominant in relatively wealthier communities close to markets and with no management plan (Fig. 3a). It suggests that future changes in wealth related to market access may affect fishing techniques being used independently of gear restrictions. Moreover, there is large amount of variation in how fishing gear differentially targeted the proportion, number, and functional traits of species (Cinner et al. 2009b, Mbaru et al. 2020). Lines mainly target large and high trophic-level species whereas spears generally target larger individuals of both herbivore and carnivore fishes (McClanahan and Mangi 2004, Davies et al. 2009). Such fishing techniques may induce changes in the structure and functioning of coral reefs through missing trophic cascades and top-down controls (Bozec et al. 2016, Rasher et al. 2017) but some functional roles performed by fishes can be replaced by other taxa, for instance, herbivores by sea urchins (Graham et al. 2017). Gill nets generally have highest catch per fisher, a low species selectivity, i.e., catch a wide range of species and functional diversity, but high size selectivity according to the 
mesh size (McClanahan and Mangi 2004, Davies et al. 2009, Mbaru et al. 2020). Gill nets capture a significant proportion (13$33 \%$ ) of key herbivores (Cinner et al. 2009b) such as grazers and scrapers/excavators that have been identified as critical to the resilience of coral reefs (Bellwood et al. 2004, Mumby et al. 2006) but also remove high proportions of juveniles (McClanahan and Mangi 2004, Mangi et al. 2007) that jeopardizes the ability of fish populations to replenish. Conversely, ecological conditions can affect gear effectiveness and gear with low selectivity such as nets can be particularly successful on degraded reefs that are dominated by herbivores (Hicks and McClanahan 2012). An understanding of the gear selectivity in northwest Madagascar would allow for effective gear-based strategies that can act as complementary strategies to existing restrictions. New or altered technologies are more likely to occur near markets and are driven by resource demand (Brewer 2013, Stevens et al. 2014). However, innovation and access to more efficient technology can generate inequality and poverty (Pauly 2006), which can lead to "socialecological traps" where the most impoverished fishers are spurred to use destructive techniques (Cinner 2011). Last, fishing practices can reflect fishers' preference for different types of fish, i.e. species or families, which could be sold at different markets according to demand. We suggest that better understanding the links between markets and fishing communities is crucial to implementing effective market-based actions that could help to regulate the effect of markets on fish stocks and fishing communities.

Second, we found that market proximity can also affect communities through the scale effect, and more specifically through both demand and displacement aspects. Relatively wealthier communities (assessed by material assets and a higher MSL score) are located closer to markets, which is consistent with other studies showing how access to major cities can change the economic, educational, and health status of societies (Weiss et al. 2018). We found that relatively wealthier communities tended to consume less fish, a finding that contrasts with previous studies showing that fish consumption is generally lower in poorer compared to wealthier households (Kawarazuka 2010). One likely explanation for our contrasting results is that we examined trends at a community, rather than household scale. Moreover, all of our study communities sold a high proportion of their catches, often directly to markets or to middlemen (Table 4, Fig. 3b, Appendix 6). Indeed, middlemen operate throughout our study region, collecting seafood products from less than two hours to eight hours away from markets (0b). In many coral reef fisheries, middlemen are essential intermediaries, collecting sea products directly from fishers and providing new trade opportunities and links to markets (Crona et al. 2010, Brewer 2013, Fröcklin et al. 2013, Dacks et al. 2018). Fish prices greatly vary over time and space (quality, seasonality, local preference, seller, buyer) however it has been shown that fish prices are generally higher close to markets (Schmitt and Kramer 2009, Brewer 2011). Middlemen can contribute to fishing income generation in remote communities while fishing households close to markets can increase their incomes by selling their catch directly to markets (Brewer 2011), especially women (Singleton et al. 2019). Most fishers lack information about market prices thus middlemen may drive fish prices down when competition is high prompting households to fish more to ensure stable incomes especially close to markets. However, we were not able to measure whether demand from middlemen influenced fishing practices or targeted fish species. Although right-based management actions, i.e., locally managed marine areas that preferentially provide access to local users, can control harvesting pressure from "outsiders," this does not prevent right holders from increasing fishing pressure to unsustainable levels. Beyond the negative influence of markets, a further investigation of the role of middlemen through the fish value chains in small-scale fisheries in Madagascar could improve the governance of fish stocks and the sustainability of coastal social-ecological systems (Crona et al. 2010, Thyresson et al. 2013, Wamukota et al. 2014, Cinner et al. 2016). Furthermore, although home ranges of fishing vessels can be used to measure the ability of fishermen to travel further away to catch more fish (Cinner et al. 2009a), all fishing vessels in our study were unmotorized. Most fishing communities in Madagascar commonly use small dugout canoes for one to four persons that are unsafe for high sea fishing, de facto restricting fishing trips' duration and geographical influence on surrounding reefs. However, increased market demand and relatively higher economic development close to markets might lead fishers to access more powerful and larger boats to expand their fishing grounds to more remote areas to maintain catch, as already demonstrated in Solomon Islands (Albert et al. 2015). Such changes could exacerbate the effect of markets and call for greater consideration of technology introductions and improvements as a consequence of economic development.

Finally, market proximity had no strong influence on the livelihood composition of coastal communities (composition effect) because we found generally low livelihood diversity (two activities per household on average) and that remote communities had no more or less livelihoods compared to communities closer to markets (Fig. 3a, Table 4). Even fishing households were generally engaged in other activities such as farming (when possible) or tourism. Our results contrast with a previous study in the Pacific islands where market proximity has been found to be positively correlated with increased income and reduced dependence on fishing (Charlton et al. 2016). One probable explanation for our contrasting results is that we considered a small coastal area rather than the whole country, where artisanal fishing remains a major contributor to food security and income of the Malagasy coastal population (Barnes-Mauthe et al. 2013). Additionally, our case study of northwest Madagascar provides new insights into how livelihoods and fishery dependence are related to this specific social-ecological context.

The importance of management to support remote communities MPAs are advocated as a critical tool to conserve marine resources (Edgar et al. 2014, Sala et al. 2018). Consistent with other studies from Madagascar (Komeno and Randriamanantsoa 2013), our study found that fish biomass was higher in reefs where fishing is prohibited compared to reefs where fishing is permitted, even though these marine managed areas (MPAs and LMMAs) were only recently established (2011 and 2015). We did not conduct before and after studies, so there are potential site selection effects observed here, i.e., sites could have been selected for reserves because they have higher initial fish biomass. Interestingly, we found fish biomass in no-take zones decayed with proximity to markets at the same rate as in areas where fishing is permitted. Similarly, a global-scale study also found that even in high compliance MPAs, fish biomass decreased along a gradient of 
human impact, suggesting there are impacts of surroundings seascapes on local resources, particularly for small MPAs (Cinner et al. 2018). In our study area, there is also a strong confounding effect between management and market accessibility because two marine managed areas (out of three) were located away ( $>$ six hours) from markets. This is consistent with previous studies showing that protected coral reefs around the world are disproportionately farther from main cities and markets (Maire et al. 2016, Cinner et al. 2018). These patterns are exacerbated by the momentum toward large offshore MPAs that target lowconflict ocean areas to rapidly meet international conservation targets (O'Leary et al. 2018), but can also jeopardize prioritizing management activities in coastal areas where overexploitation can threaten the sustainability of marine resources. Effective governance of marine managed areas is necessary to achieve biodiversity conservation objectives and socioeconomic development (Watson et al. 2016). Shared governance involving nongovernmental organizations (NGOs) and local communities may help the expansion of Madagascar's protected area system but has shown mixed results regarding conservation effectiveness (Gardner et al. 2018). Thus, future policies will face the challenge described in the Sustainable Development Goals (Rees et al. 2018) mixing nature conservation and human development.

\section{Limitations of the study}

The recent establishment of Ankarea and Ankivonjy MPAs could suggest that fish biomass was initially higher in those areas, and that this higher biomass might be more attributed to its longlasting isolation from markets and relatively lower human population rather than the effect of protection per se. Moreover, there has not been an assessment of the level of compliance in these MPAS and we do recognize that levels of compliance within the "fishing prohibited" category (no-take zones within Ankarea and Ankivonjy MPAs and Nosy Tanikely National Park) may vary. However, we found that fish biomass was much higher in reefs where fishing is prohibited than in reefs where fishing is permitted (Fig. 2d) suggesting that compliance is relatively high in all no-take zones.

Although our findings suggest that the effects of market proximity could vary according to the characteristics of the nearest market, we could not find any relevant aspect. The three markets considered in our study (Ambanja, Hell Ville, Ambilobe) have similar demographic and economic aspects. We can assume that middlemen have strong links with specific fishers and also preferred markets to sell fish. Further work is needed to better understand how middlemen operate and how they affect marine resource exploitation in our study area.

Although recent studies have suggested that higher catches in remote communities might be because of the presence of middlemen (Dacks et al. 2018), we could not unravel the direct effects of middlemen on coastal resources in our study. Also, there is a strong confounding effect between management actions and market accessibility because the two community comanaged MPAs (Ankarea and Ankivonjy) under study were located away from markets and no open-access areas were found far from markets. Although it was difficult to disentangle the relative effect of management and accessibility on communities' characteristics, we provide some evidence on the role of markets in shaping the fishing practices of local communities while also accounting for management. Further work is therefore needed to assess how fishing strategies in coastal communities are shaped by remoteness and limited access to markets, particularly in developing countries.

\section{CONCLUSION}

Community characteristics, management, and market access influenced fish biomass in this case study of northwest Madagascar. We found that market proximity and characteristics affected coastal communities mainly through the technique and the scale effects, which ultimately can lead to changes in the exploitation and sustainability of marine resources. Markets also shaped reef fish biomass independently of management while the effect of fishing communities interacted with management. Understanding the human-environmental interrelations relies on a scaling-down to highlight the drivers of resource use and governance by considering households behaviors and decision making. A better assessment of how human societies and markets can influence social-ecological characteristics of sustainability is thus a critical step toward long-term management of the coral reef fisheries.

Responses to this article can be read online at: http://www.ecologyandsociety.org/issues/responses. php/11595

\begin{abstract}
Acknowledgments:
We thank the communities we work with and the support of the local and national governments, especially the Ministry for Marine Resources and Fisheries and Ministry for Environment, Ecology, Oceans and Forests. We are grateful to Professor Christina C. Hicks for her support and comments. We thank Professor Marco Janssen as well as three anonymous reviewers for their comments, which prompted significant improvements.
\end{abstract}

Data Availability Statement:

Data and code used for the analyses are freely available and can be found at https://github.com/EvaMaire/Markets_NWMadagascar

\section{LITERATURE CITED}

Ahmed, S. E., A. C. Lees, N. G. Moura, T. A. Gardner, J. Barlow, J. Ferreira, and R. M. Ewers. 2014. Road networks predict human influence on Amazonian bird communities. Proceedings of the Royal Society B: Biological Sciences 281(1795). https://doi. org/10.1098/rspb.2014.1742

Alamgir, M., M. J. Campbell, S. Sloan, M. Goosem, G. R. Clements, M. I. Mahmoud, and W. F. Laurance. 2017. Economic, socio-political and environmental risks of road development in the tropics. Current Biology 27(20):1130-1140. https://doi. org/10.1016/j.cub.2017.08.067

Albert, S., S. Aswani, P. L. Fisher, and J. Albert. 2015. Keeping food on the table: human responses and changing coastal fisheries in Solomon Islands. PLoS ONE 10(7):e0130800. https://doi. org/10.1371/journal.pone.0130800 
Barber, C. P., M. A. Cochrane, C. M. Souza, and W. F. Laurance. 2014. Roads, deforestation, and the mitigating effect of protected areas in the Amazon. Biological Conservation 177:203-209. https://doi.org/10.1016/j.biocon.2014.07.004

Barnes-Mauthe, M., K. L. L. Oleson, and B. Zafindrasilivonona. 2013. The total economic value of small-scale fisheries with a characterization of post-landing trends: an application in Madagascar with global relevance. Fisheries Research 147:175-185. https://doi.org/10.1016/j.fishres.2013.05.011

Bell, J. D., M. Kronen, A. Vunisea, W. J. Nash, G. Keeble, A. Demmke, S. Pontifex, and S. Andréfouët. 2009. Planning the use of fish for food security in the Pacific. Marine Policy 33(1):64-76. https://doi.org/10.1016/j.marpol.2008.04.002

Bellwood, D. R., T. P. Hughes, C. Folke, and M. Nyström. 2004. Confronting the coral reef crisis. Nature 429(6994):827-833. https://doi.org/10.1038/nature02691

Béné, C., G. Macfadyen, and E. H. Allison. 2007. Increasing the contribution of small-scale fisheries to poverty alleviation and food security. FAO Fisheries Technical Paper No 481. FAO, Rome, Italy.

Berkes, F., T. P. Hughes, R. S. Steneck, J. A. Wilson, D. R. Bellwood, B. Crona, C. Folke, L. H. Gunderson, H. M. Leslie, J. Norberg, M. Nyström, P. Olsson, H. Österblom, M. Scheffer, and B. Worm. 2006. Globalization, roving bandits, and marine resources. Science 311(5767):1557-1558. https://doi.org/10.1126/ science. 1122804

Beyer, H. L., E. V. Kennedy, M. Beger, C. A. Chen, J. E. Cinner, E. S. Darling, C. M. Eakin, R. D. Gates, S. F. Heron, N. Knowlton, D. O. Obura, S. R. Palumbi, H. P. Possingham, M. Puotinen, R. K. Runting, W. J. Skirving, M. Spalding, K. A. Wilson, S. Wood, J. E. Veron, and O. Hoegh-Guldberg. 2018. Risk-sensitive planning for conserving coral reefs under rapid climate change. Conservation Letters 11(6):e12587. https://doi.org/10.1111/ conl.12587

Bozec, Y. M., S. O'Farrell, J. H. Bruggemann, B. E. Luckhurst, and P. J. Mumby. 2016. Tradeoffs between fisheries harvest and the resilience of coral reefs. Proceedings of the National Academy of Sciences 113(16):4536-4541. https://doi.org/10.1073/pnas.1601529113

Brewer, T. D. 2011. Coral reef fish value chains in Solomon Islands: market opportunities and market effects on fish stocks. ARC Centre of Excellence for Coral Reef Studies report to Solomon Islands Ministry of Fisheries and Marine Resources and Secretariat of the Pacific Community. James Cook University, Townsville, Australia.

Brewer, T. D. 2013. Dominant discourses, among fishers and middlemen, of the factors affecting coral reef fish distributions in Solomon Islands. Marine Policy 37:245-253. https://doi. org/10.1016/j.marpol.2012.05.006

Brewer, T. D., J. E. Cinner, R. Fisher, A. Green, and S. K. Wilson. 2012. Market access, population density, and socioeconomic development explain diversity and functional group biomass of coral reef fish assemblages. Global Environmental Change 22 (2):399-406. https://doi.org/10.1016/j.gloenvcha.2012.01.006
Brokovich, E., S. Einbinder, N. Shashar, M. Kiflawi, and S. Kark. 2008. Descending to the twilight-zone: changes in coral reef fish assemblages along a depth gradient down to $65 \mathrm{~m}$. Marine Ecology Progress Series 371:253-262. https://doi.org/10.3354/meps07591

Carter, M. R., and C. B. Barrett. 2006. The economics of poverty traps and persistent poverty: an asset-based approach. Journal of Development Studies 42(2):178-199. https://doi.org/10.1080/00220380500405261

Charlton, K. E., J. Russell, E. Gorman, Q. Hanich, A. Delisle, B. Campbell, and J. Bell. 2016. Fish, food security and health in Pacific Island countries and territories: a systematic literature review. BMC Public Health. 16:285. https://doi.org/10.1186/ s12889-016-2953-9

Chaves, W. A., D. S. Wilkie, M. C. Monroe, and K. E. Sieving. 2017. Market access and wild meat consumption in the central Amazon, Brazil. Biological Conservation 212:240-248. https://doi. org/10.1016/j.biocon.2017.06.013

Cinner, J. E. 2011. Social-ecological traps in reef fisheries. Global Environmental Change 21(3):835-839. https://doi.org/10.1016/j. gloenvcha.2011.04.012

Cinner, J. E., and Ö. Bodin. 2010. Livelihood diversification in tropical coastal communities: a network-based approach to analyzing 'livelihood landscapes.' PLOS ONE 5(8):e11999. https://doi.org/10.1371/journal.pone.0011999

Cinner, J. E., N. A. J. Graham, C. Huchery, and M. A. MacNeil. 2013. Global effects of local human population density and distance to markets on the condition of coral reef fisheries. Conservation Biology 27(3):453-458. https://doi.org/10.1111/ j.1523-1739.2012.01933.x

Cinner, J. E., C. Huchery, M. A. MacNeil, N. A. J. Graham, T. R. McClanahan, J. Maina, E. Maire, J. N. Kittinger, C. C. Hicks, C. Mora, E. H. Allison, S. D'Agata, A. Hoey, D. A. Feary, L. Crowder, I. D. Williams, M. Kulbicki, L. Vigliola, L. Wantiez, G. Edgar, R. D. Stuart-Smith, S. A. Sandin, A. L. Green, M. J. Hardt, M. Beger, A. Friedlander, S. J. Campbell, K. E. Holmes, S. K. Wilson, E. Brokovich, A. J. Brooks, J. J. Cruz-Motta, D. J. Booth, P. Chabanet, C. Gough, M. Tupper, S. C. A. Ferse, U. R. Sumaila, and D. Mouillot. 2016. Bright spots among the world's coral reefs. Nature 535:416-419. https://doi.org/10.1038/nature18607

Cinner, J. E., E. Maire, C. Huchery, M. A. MacNeil, N. A. J. Graham, C. Mora, T. R. McClanahan, M. L. Barnes, J. N. Kittinger, C. C. Hicks, S. D’Agata, A. S. Hoey, G. G. Gurney, D. A. Feary, I. D. Williams, M. Kulbicki, L. Vigliola, L. Wantiez, G. J. Edgar, R. D. Stuart-Smith, S. A. Sandin, A. Green, M. J. Hardt, M. Beger, A. M. Friedlander, S. K. Wilson, E. Brokovich, A. J. Brooks, J. J. Cruz-Motta, D. J. Booth, P. Chabanet, C. Gough, M. Tupper, S. C. A. Ferse, U. R. Sumaila, S. Pardede, and D. Mouillot. 2018. Gravity of human impacts mediates coral reef conservation gains. Proceedings of the National Academy of Sciences 115(27):E6116-E6125. https://doi.org/10.1073/pnas.1708001115

Cinner, J. E., T. R. McClanahan, T. M. Daw, N. A. J. Graham, J. Maina, S. K. Wilson, and T. P. Hughes. 2009a. Linking social and ecological systems to sustain coral reef fisheries. Current Biology 19(3):206-212. https://doi.org/10.1016/j.cub.2008.11.055 
Cinner, J. E., T. R. McClanahan, N. A. J. Graham, M. S. Pratchett, S. K. Wilson, and J.-B. Raina. 2009b. Gear-based fisheries management as a potential adaptive response to climate change and coral mortality. Journal of Applied Ecology 46(3):724-732. https://doi.org/10.1111/j.1365-2664.2009.01648.x

Conservation International. 2015. Monitoring natural capital and human well-being in Madagascar: national indicators for sustainable development. Conservation International, Arlington, Virginia, USA.

Coulthard, S., L. Evans, R. Turner, D. Mills, S. Foale, K. Abernethy, C. Hicks, and I. Monnereau. 2017. Exploring 'islandness' and the impacts of nature conservation through the lens of wellbeing. Environmental Conservation 44(3):298-309. https://doi.org/10.1017/S0376892917000273

Crona, B., M. Nyström, C. Folke, and N. Jiddawi. 2010. Middlemen, a critical social-ecological link in coastal communities of Kenya and Zanzibar. Marine Policy 34 (4):761-771. https://doi.org/10.1016/j.marpol.2010.01.023

D'Agata, S., D. Mouillot, L. Wantiez, A. M. Friedlander, M. Kulbicki, and L. Vigliola. 2016. Marine reserves lag behind wilderness in the conservation of key functional roles. Nature Communications 7:12000. https://doi.org/10.1038/ncomms12000

Dacks, R., T. Ticktin, S. D. Jupiter, and A. Friedlander. 2018. Drivers of fishing at the household scale in Fiji. Ecology and Society 23(1):37. https://doi.org/10.5751/ES-09989-230137

Davies, T. E., N. Beanjara, and T. Tregenza. 2009. A socioeconomic perspective on gear-based management in an artisanal fishery in south-west Madagascar. Fisheries Management and Ecology 16(4):279-289. https://doi.org/10.1111/j.1365-2400.2009.00665. $\underline{\mathrm{x}}$

Delgado, C. L., N. Wada, M. W. Rosegrant, S. Meijer, and M. Ahmed. 2003. Fish to 2020: supply and demand in changing global markets. WorldFish, Penang, Malaysia.

Dobson, A. P., M. Borner, A. R. E. Sinclair, P. J. Hudson, T. M. Anderson, G. Bigurube, T. B. B. Davenport, J. Deutsch, S. M. Durant, R. D. Estes, A. B. Estes, J. Fryxell, C. Foley, M. E. Gadd, D. Haydon, R. Holdo, R. D. Holt, K. Homewood, J. G. C. Hopcraft, R. Hilborn, G. L. K. Jambiya, M. K. Laurenson, L. Melamari, A. O. Morindat, J. O. Ogutu, G. Schaller, and E. Wolanski. 2010. Road will ruin Serengeti. Nature 467:272-273. https://doi.org/10.1038/467272a

Doukakis, P., M. Jonahson, V. Ramahery, B. J. de Dieu Randriamanantsoa, and S. Harding. 2008. Traditional fisheries of Antongil Bay, Madagascar. Western Indian Ocean Journal of Marine Science 6(2):175-181. https://doi.org/10.4314/wiojms. $\underline{\mathrm{v} 6 \mathrm{i} 2.48237}$

Edgar, G. J., R. D. Stuart-Smith, T. J. Willis, S. Kininmonth, S. C. Baker, S. Banks, N. S. Barrett, M. A. Becerro, A. T. F. Bernard, J. Berkhout, C. D. Buxton, S. J. Campbell, A. T. Cooper, M. Davey, S. C. Edgar, G. Försterra, D. E. Galván, A. J. Irigoyen, D. J. Kushner, R. Moura, P. E. Parnell, N. T. Shears, G. Soler, E. M. A. Strain, and R. J. Thomson. 2014. Global conservation outcomes depend on marine protected areas with five key features. Nature 506:216-220. https://doi.org/10.1038/nature13022
Ferrari, R., M. Bryson, T. Bridge, J. Hustache, S. B. Williams, M. Byrne, and W. Figueira. 2016. Quantifying the response of structural complexity and community composition to environmental change in marine communities. Global Change Biology 22(5):1965-1975. https://doi.org/10.1111/gcb.13197

Food and Agriculture Organization, International Fund for Agricultural Development, UNICEF, World Food Programme, and WHO (FAO, IFAD, UNICEF, WFP, and WHO). 2018. The state of food security and nutrition in the world 2018. Building climate resilience for food security and nutrition. FAO, Rome, Italy. https://doi.org/10.18356/c94f150c-en

Fröcklin, S., M. de la Torre-Castro, L. Lindström, and N. S. Jiddawi. 2013. Fish traders as key actors in fisheries: gender and adaptive management. Ambio 42:951-962. https://doi.org/10.1007/ s13280-013-0451-1

Froese, R., and D. Pauly. 2012. FishBase. [online] URL: https:// www.fishbase.org

Gardner, C. J., M. E. Nicoll, C. Birkinshaw, A. Harris, R. E. Lewis, D. Rakotomalala, and A. N. Ratsifandrihamanana. 2018. The rapid expansion of Madagascar's protected area system. Biological Conservation 220:29-36. https://doi.org/10.1016/j. biocon.2018.02.011

Govan, H., A. Tawake, K. Tabunakawai, A. Jenkins, A. Lasgorceix, A. M. Schwarz, B. Aalbersberg, B. Manele, C. Vieux, and D. Notere. 2009. Status and potential of locally-managed marine areas in the South Pacific: meeting nature conservation and sustainable livelihood targets through wide-spread implementation of LMMAs. Secretariat of the Pacific Regional Environment Programme (SPREP), World Wide Fund for Nature (WWF), WorldFish-Reefbase, and CRISP.

Graham, N. A. J., T. R. McClanahan, M. A. MacNeil, S. K. Wilson, J. E. Cinner, C. Huchery, and T. H. Holmes. 2017. Human disruption of coral reef trophic structure. Current Biology 27 (2):231-236. https://doi.org/10.1016/j.cub.2016.10.062

Grossman, G. M., and A. B. Krueger. 1995. Economic growth and the environment. Quarterly Journal of Economics 110 (2):353-377. https://doi.org/10.2307/2118443

Gurney, G. G., and E. S. Darling. 2017. A global social-ecological systems monitoring framework for coastal fisheries management: a practical monitoring handbook. Wildlife Conservation Society, New York, New York, USA.

Harris, A. R. 2011. Out of sight but no longer out of mind: a climate of change for marine conservation in Madagascar. Madagascar Conservation \& Development 6(1):7-14. https://doi. org/10.4314/mcd.v6i1.68058

Hastie, T. J., and R. J. Tibshirani. 1990. Generalized additive models. Volume 43 of Monographs on Statistics and Applied Probability. Chapman \& Hall, London, UK.

Hicks, C. C., and T. R. McClanahan. 2012. Assessing gear modifications needed to optimize yields in a heavily exploited, multi-species, seagrass and coral reef fishery. PLoS ONE 7(5): e36022. https://doi.org/10.1371/journal.pone.0036022

Hill, J., and C. Wilkinson. 2004. Methods for ecologicalmonitoring of coral reefs. Australian Institute of Marine Science, Townsville, Australia. 
Huot, Y., M. Babin, F. Bruyant, C. Grob, M. S. Twardowski, and H. Claustre. 2007. Does chlorophyll $a$ provide the best index of phytoplankton biomass for primary productivity studies? Biogeosciences Discussions 4(2):707-745.

Hurvich, C. M., and C.-L. Tsai. 1989. Regression and time series model selection in small samples. Biometrika 76(2):297-307. https://doi.org/10.1093/biomet/76.2.297

Jadot, C., E. S. Darling, and A. Brenier. 2015. Madagascar: a baseline assessment of coral reef fisheries. Wildlife Conservation Society, Bronx, New York, USA.

Januchowski-Hartley, F. A., L. Vigliola, E. Maire, M. Kulbicki, and D. Mouillot. 2020. Low fuel cost and rising fish price threaten coral reef wilderness. Conservation Letters e12706. https://doi. org/10.1111/conl.12706

Jupiter, S. D., P. J. Cohen, R. Weeks, A. Tawake, and H. Govan. 2014. Locally-managed marine areas: multiple objectives and diverse strategies. Pacific Conservation Biology 20(2):165-179. https://doi.org/10.1071/PC140165

Kawarazuka, N. 2010. The contribution of fish intake, aquaculture, and small-scale fisheries to improving nutrition: a literature review. The WorldFish Center Working Paper no. 2106. The WorldFish Center, Penang, Malaysia.

Komeno, R., and B. Randriamanantsoa. 2013. Assessing ecological impacts of Antongil Bay LMMAs. Wildlife Conservation Society, Bronx, New York.

Kramer, D. B., K. Stevens, N. E. Williams, S. A. Sistla, A. B. Roddy, and G. R. Urquhart. 2017. Coastal livelihood transitions under globalization with implications for trans-ecosystem interactions. PLoS ONE 12(10):e0186683. https://doi.org/10.1371/ journal.pone. 0186683

Kulbicki, M., N. Guillemot, and M. Amand. 2005. A general approach to length-weight relationships for New Caledonian lagoon fishes. Cybium 29(3):235-252.

Labrosse, P., M. Kulbicki, and J. Ferraris. 2002. Underwater visual fish census surveys: proper use and implementation. Reef Resources Assessment Tools. Secretariat of the Pacific Community, Nouméa, New Caledonia.

Lange, G.-M., Q. Wodon, and K. Carey. 2018. The changing wealth of nations 2018: building a sustainable future. World Bank, Washington, D.C., USA.

Laroche, J., and N. Ramananarivo. 1995. A preliminary survey of the artisanal fishery on coral reefs of the Tulear Region (southwest Madagascar). Coral Reefs 14:193-200. https://doi. org/10.1007/BF00334341

Laurance, W. F., M. Goosem, and S. G. W. Laurance. 2009. Impacts of roads and linear clearings on tropical forests. Trends in Ecology \& Evolution 24(12):659-669. https://doi.org/10.1016/j. tree.2009.06.009

Le Manach, F., C. Gough, A. Harris, F. Humber, S. Harper, and D. Zeller. 2012. Unreported fishing, hungry people and political turmoil: the recipe for a food security crisis in Madagascar? Marine Policy 36(1):218-225. https://doi.org/10.1016/j.marpol.2011.05.007
Liu, J., V. Hull, M. Batistella, R. DeFries, T. Dietz, F. Fu, T. W. Hertel, R. C. Izaurralde, E. F. Lambin, S. Li, L. A. Martinelli, W. J. McConnell, E. F. Moran, R. Naylor, Z. Ouyang, K. R. Polenske, A. Reenberg, G. de Miranda Rocha, C. S. Simmons, P. H. Verburg, P. M. Vitousek, F. Zhang, and C. Zhu. 2013. Framing sustainability in a telecoupled world. Ecology and Society 18 (2):26. https://doi.org/10.5751/ES-05873-180226

Liu, J., H. Mooney, V. Hull, S. J. Davis, J. Gaskell, T. Hertel, J. Lubchenco, K. C. Seto, P. Gleick, C. Kremen, and S. Li. 2015. Systems integration for global sustainability. Science 347 (6225):1258832. https://doi.org/10.1126/science.1258832

Luckhurst, B. E., and K. Luckhurst. 1978. Analysis of the influence of substrate variables on coral reef fish communities. Marine Biology 49:317-323. https://doi.org/10.1007/bf00455026

Maire, E., J. Cinner, L. Velez, C. Huchery, C. Mora, S. Dagata, L. Vigliola, L. Wantiez, M. Kulbicki, and D. Mouillot. 2016. How accessible are coral reefs to people? A global assessment based on travel time. Ecology Letters 19(4):351-360. https://doi. org/10.1111/ele. 12577

Mangi, S. C., C. M. Roberts, and L. D. Rodwell. 2007. Financial comparisons of fishing gear used in Kenya's coral reef lagoons. Ambio 36(8):671-676. https://doi.org/10.1579/0044-7447(2007)36 [671:FCOFGU]2.0.CO:2

Mbaru, E. K., N. A. J. Graham, T. R. McClanahan, and J. E. Cinner. 2020. Functional traits illuminate the selective impacts of different fishing gears on coral reefs. Journal of Applied Ecology 57(2):241-252. https://doi.org/10.1111/1365-2664.13547

McCauley, D. J., E. A. Power, D. W. Bird, A. McInturff, R. B. Dunbar, W. H. Durham, F. Micheli, and H. S. Young. 2013. Conservation at the edges of the world. Biological Conservation 165:139-145. https://doi.org/10.1016/j.biocon.2013.05.026

McClanahan, T. R., N. A. J. Graham, M. A. MacNeil, N. A. Muthiga, J. E. Cinner, J. H. Bruggemann, and S. K. Wilson. 2011 a. Critical thresholds and tangible targets for ecosystem-based management of coral reef fisheries. Proceedings of the National Academy of Sciences 108(41):17230-17233. https://doi.org/10.1073/ pnas. 1106861108

McClanahan, T. R., J. M. Maina, N. A. J. Graham, and K. R. Jones. 2016. Modeling reef fish biomass, recovery potential, and management priorities in the Western Indian Ocean. PLoS ONE 11(5):e0154585. https://doi.org/10.1371/journal.pone.0154585

McClanahan, T. R., J. M. Maina, and N. A. Muthiga. $2011 b$. Associations between climate stress and coral reef diversity in the Western Indian Ocean. Global Change Biology 17(6):2023-2032. https://doi.org/10.1111/j.1365-2486.2011.02395.X

McClanahan, T. R., and S. C. Mangi. 2004. Gear-based management of a tropical artisanal fishery based on species selectivity and capture size. Fisheries Management and Ecology 11(1):51-60. https://doi.org/10.1111/j.1365-2400.2004.00358.x

McCormick, M. I. 1994. Comparison of field methods for measuring surface topography and their associations with a tropical reef fish assemblage. Marine Ecology Progress Series 112:87-96. https://doi.org/10.3354/meps112087 
McKenna, S. A., and G. R. Allen. 2003. A rapidmarine biodiversity assessment of northwest Madagascar. Bulletin of the Rapid Assessment Program 31. Conservation International, Washington, D.C., USA.

Mora, C., O. Aburto-Oropeza, A. A. Bocos, P. M. Ayotte, S. Banks, A. G. Bauman, M. Beger, S. Bessudo, D. J. Booth, E. Brokovich, A. Brooks, P. Chabanet, J. E. Cinner, J. Cortés, J. J. Cruz-Motta, A. C. Magaña, E. E. DeMartini, G. J. Edgar, D. A. Feary, S. C. A. Ferse, A. M. Friedlander, K. J. Gaston, C. Gough, N. A. J. Graham, A. Green, H. Guzman, M. Hardt, M. Kulbicki, Y. Letourneur, A. L. Pérez, M. Loreau, Y. Loya, C. Martinez, I. Mascareñas-Osorio, T. Morove, M.-O. Nadon, Y. Nakamura, G. Paredes, N. V. C. Polunin, M. S. Pratchett, H. R. Bonilla, F. Rivera, E. Sala, S. A. Sandin, G. Soler, R. Stuart-Smith, E. Tessier, D. P. Tittensor, M. Tupper, P. Usseglio, L. Vigliola, L. Wantiez, I. Williams, S. K. Wilson, and F. A. Zapata. 2011. Global human footprint on the linkage between biodiversity and ecosystem functioning in reef fishes. PLOS Biology 9(4):e1000606. https:// doi.org/10.1371/journal.pbio.1000606

Mora, C., I. R. Caldwell, C. Birkeland, and J. W. McManus. 2016. Dredging in the Spratly Islands: gaining land but losing reefs. PLOS Biology 14(6):e1002497. https://doi.org/10.1371/journal. pbio. 1002422

Mumby, P. J., C. P. Dahlgren, A. R. Harborne, C. V. Kappel, F. Micheli, D. R. Brumbaugh, K. E. Holmes, J. M. Mendes, K. Broad, J. N. Sanchirico, K. Buch, S. Box, R. W. Stoffle, and A. B. Gill. 2006. Fishing, trophic cascades, and the process of grazing on coral reefs. Science 311(5757):98-101. https://doi.org/10.1126/ science. 1121129

Nash, K. L., N. A. J. Graham, S. K. Wilson, and D. R. Bellwood. 2013. Cross-scale habitat structure drives fish body size distributions on coral reefs. Ecosystems 16:478-490. https://doi. org/10.1007/s10021-012-9625-0

Norström, A. V., M. Nyström, J. Lokrantz, and C. Folke. 2009. Alternative states on coral reefs: beyond coral-macroalgal phase shifts. Marine Ecology Progress Series 376:295-306. https://doi. org/10.3354/meps07815

O’Leary, B. C., N. C. Ban, M. Fernandez, A. M. Friedlander, P. García-Borboroglu, Y. Golbuu, P. Guidetti, J. M. Harris, J. P. Hawkins, T. Langlois, D. J. McCauley, E. K. Pikitch, R. H. Richmond, and C. M. Roberts. 2018. Addressing criticisms of large-scale marine protected areas. BioScience 68(5):359-370. https://doi.org/10.1093/biosci/biy021

Obura, D. 2012. The diversity and biogeography of Western Indian Ocean reef-building corals. PLoS ONE 7(9):e45013. https://doi.org/10.1371/journal.pone.0045013

Pauly, D. 2006. Major trends in small-scale marine fisheries, with emphasis on developing countries, and some implications for the social sciences. Maritime Studies 4:7-22.

Pollnac, R. B., and B. R. Crawford. 2000. Assessing behavioral aspects of coastal resource use. Coastal Resources Center, Narragansett, Rhode Island, USA.

Rakotoson, L. R., and K. Tanner. 2006. Community-based governance of coastal zone and marine resources in Madagascar. Ocean \& Coastal Management 49(11):855-872. https://doi. org/10.1016/j.ocecoaman.2006.08.003
Rasher, D. B., A. S. Hoey, and M. E. Hay. 2017. Cascading predator effects in a Fijian coral reef ecosystem. Scientific Reports 7:15684. https://doi.org/10.1038/s41598-017-15679-w

Rees, S. E., S. J. Pittman, N. Foster, O. Langmead, C. Griffiths, S. Fletcher, D. E. Johnson, and M. Attrill. 2018. Bridging the divide: social-ecological coherence in marine protected area network design. Aquatic Conservation: Marine and Freshwater Ecosystems 28(3):754-763. https://doi.org/10.1002/aqc.2885

Roberts, C. M., and R. F. G. Ormond. 1987. Habitat complexity and coral reef fish diversity and abundance on Red Sea fringing reefs. Marine Ecology Progress Series 41:1-8. https://doi. org/10.3354/meps041001

Rockström, J., W. Steffen, K. Noone, Å. Persson, F. S. Chapin III, E. Lambin, T. M. Lenton, M. Scheffer, C. Folke, H. J. Schellnhuber, B. Nykvist, C. A. De Wit, T. Hughes, S. van der Leeuw, H. Rodhe, S. Sörlin, P. K. Snyder, R. Costanza, U. Svedin, M. Falkenmark, L. Karlberg, R. W. Corell, V. J. Fabry, J. Hansen, B. Walker, D. Liverman, K. Richardson, P. Crutzen, and J. Foley. 2009. Planetary boundaries: exploring the safe operating space for humanity. Ecology and Society 14(2):32. https://doi. org/10.5751/ES-03180-140232

Rocliffe, S., S. Peabody, M. Samoilys, and J. P. Hawkins. 2014. Towards a network of locally managed marine areas (LMMAs) in the Western Indian Ocean. PLoS ONE 9(7):e103000. https:// doi.org/10.1371/journal.pone. 0103000

Sala, E., J. Lubchenco, K. Grorud-Colvert, C. Novelli, C. Roberts, and U. R. Sumaila. 2018. Assessing real progress towards effective ocean protection. Marine Policy 91:11-13. https://doi. org/10.1016/j.marpol.2018.02.004

Schmitt, K. M., and D. B. Kramer. 2009. Road development and market access on Nicaragua's Atlantic coast: implications for household fishing and farming practices. Environmental Conservation 36(4):289-300. https://doi.org/10.1017/S0376892910000159

Selgrath, J. C., S. E. Gergel, and A. C. J. Vincent. 2018. Shifting gears: diversification, intensification, and effort increases in small-scale fisheries (1950-2010). PLoS ONE 13(3):e0190232. https://doi.org/10.1371/journal.pone.0190232

Singleton, R. L., E. H. Allison, C. Gough, V. Kamat, P. LeBillon, L. Robson, and U. R. Sumaila. 2019. Conservation, contraception and controversy: supporting human rights to enable sustainable fisheries in Madagascar. Global Environmental Change 59:101946. https://doi.org/10.1016/j.gloenvcha.2019.101946

Srinivasan, M. 2003. Depth distributions of coral reef fishes: the influence of microhabitat structure, settlement, and postsettlement processes. Oecologia 137:76-84. https://doi.org/10.1007/ $\underline{\mathrm{s} 00442-003-1320-6}$

Steffen, W., J. Grinevald, P. Crutzen, and J. McNeill. 2011. The Anthropocene: conceptual and historical perspectives. Philosophical Transactions of the Royal Society A: Mathematical, Physical and Engineering Sciences 369(1938):842. https://doi.org/10.1098/ rsta.2010.0327

Stella, J. S., M. S. Pratchett, P. A. Hutchings, and G. P. Jones. 2011. Diversity, importance and vulnerability of coral-associated invertebrates. Oceanography and Marine Biology: An Annual Review 49:43-104. 
Stevens, K., B. Irwin, D. Kramer, and G. Urquhart. 2014. Impact of increasing market access on a tropical small-scale fishery. Marine Policy 50:46-52. https://doi.org/10.1016/j.marpol.2014.05.007

Sugiawan, Y., M. Islam, and S. Managi. 2017. Global marine fisheries with economic growth. Economic Analysis and Policy 55:158-168. https://doi.org/10.1016/j.eap.2017.08.004

Tatem, A. J. 2017. WorldPop, open data for spatial demography. Scientific Data 4:170004. https://doi.org/10.1038/sdata.2017.4

Teh, L. S. L., L. C. L. Teh, and U. R. Sumaila. 2013. A global estimate of the number of coral reef fishers. PLOS ONE 8(6): e65397. https://doi.org/10.1371/journal.pone.0065397

Thyresson, M., B. Crona, M. Nyström, M. de la Torre-Castro, and N. Jiddawi. 2013. Tracing value chains to understand effects of trade on coral reef fish in Zanzibar, Tanzania. Marine Policy 38:246-256. https://doi.org/10.1016/j.marpol.2012.05.041

Thyresson, M., M. Nyström, and B. Crona. 2011. Trading with resilience: parrotfish trade and the exploitation of key-ecosystem processes in coral reefs. Coastal Management 39(4):396-411. https://doi.org/10.1080/08920753.2011.589226

Tregidgo, D. J., J. Barlow, P. S. Pompeu, M. de Almeida Rocha, and L. Parry. 2017. Rainforest metropolis casts 1,000-km defaunation shadow. Proceedings of the National Academy of Sciences 114(32):8655-8659. https://doi.org/10.1073/pnas.1614499114

Tsurumi, T., and S. Managi. 2010. Decomposition of the environmental Kuznets curve: scale, technique, and composition effects. Environmental Economics and Policy Studies 11:19-36. https://doi.org/10.1007/s10018-009-0159-4

Wamukota, A., T. D. Brewer, and B. Crona. 2014. Market integration and its relation to income distribution and inequality among fishers and traders: the case of two small-scale Kenyan reef fisheries. Marine Policy 48:93-101. https://doi.org/10.1016/j. marpol.2014.03.013

Watson, J. E. M., E. S. Darling, O. Venter, M. Maron, J. Walston, H. P. Possingham, N. Dudley, M. Hockings, M. Barnes, and T. M. Brooks. 2016. Bolder science needed now for protected areas. Conservation Biology 30(2):243-248. https://doi.org/10.1111/ cobi.12645

Weiss, D. J., A. Nelson, H. S. Gibson, W. Temperley, S. Peedell, A. Lieber, M. Hancher, E. Poyart, S. Belchior, N. Fullman, B. Mappin, U. Dalrymple, J. Rozier, T. C. D. Lucas, R. E. Howes, L. S. Tusting, S. Y. Kang, E. Cameron, D. Bisanzio, K. E. Battle, S. Bhatt, and P. W. Gething. 2018. A global map of travel time to cities to assess inequalities in accessibility in 2015. Nature 553:333-336. https://doi.org/10.1038/nature25181

Westerman, K., and C. J. Gardner. 2013. Adoption of sociocultural norms to increase community compliance in permanent marine reserves in southwest Madagascar. Conservation Evidence 10:4-9.

Williams, I. D., J. K. Baum, A. Heenan, K. M. Hanson, M. O. Nadon, and R. E. Brainard. 2015. Human, oceanographic and habitat drivers of Central and Western Pacific coral reef fish assemblages. PLOS ONE 10(5):e0129407. https://doi.org/10.1371/ journal.pone. 0120516
Wilson, S. K., N. A. J. Graham, and N. V. C. Polunin. 2007. Appraisal of visual assessments of habitat complexity and benthic composition on coral reefs. Marine Biology 151:1069-1076. https://doi.org/10.1007/s00227-006-0538-3

Wood, S. N. 2006. Generalized additive models: an introduction with R. CRC, Boca Raton, Florida, USA.

World Bank. 2010. Madagascar country profile. World Bank, Washington, D.C., USA. 
Appendix 1. Associations between environmental and benthic conditions of reefs through a Principal Component Analysis and corresponding loadings. The two first components (PC1 and PC2) mix both environmental and benthic variables and explain $56 \%$ of the variation observed between reefs. PC1 mostly reflects hard coral cover and complexity (i.e., reef condition and habitat quality) and PC2 mostly describes macroalgae and depth, two factors that can affect fish composition and biomass. PC1 and PC2 reflect potential ecological drivers of reef fish biomass and, as such, are important to retain in the models.

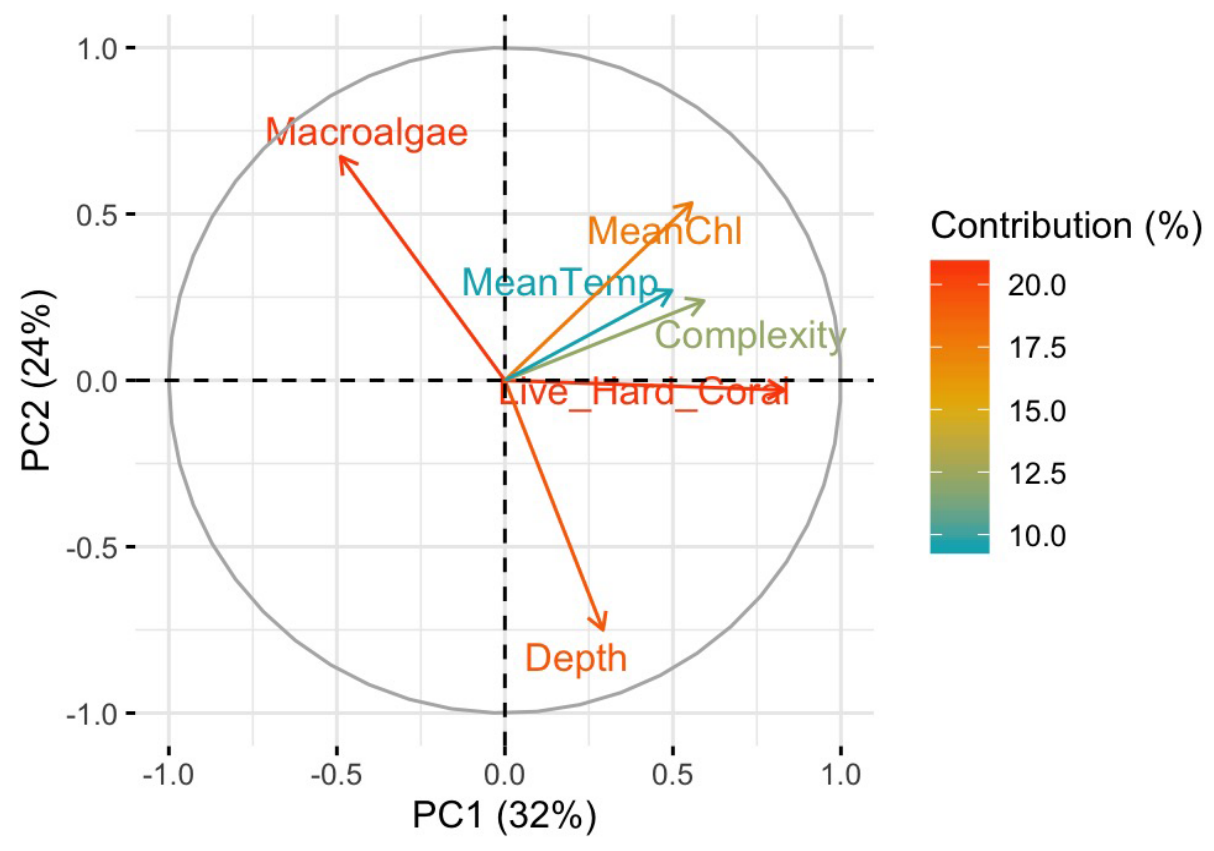

PC1 PC2 PC3 PC4 PC5

Depth $\quad 0.21 \quad-0.63 \quad 0.43 \quad 0.07 \quad 0.25$

Live_Hard_Coral $0.6 \quad-0.02 \quad-0.11 \quad 0.31 \quad-0.72$

$\begin{array}{llllll}\text { Macroalgae } & -0.35 & 0.56 & 0.27 & 0.44 & -0.08\end{array}$

$\begin{array}{llllll}\text { Complexity } & 0.43 & 0.2 & -0.53 & 0.34 & 0.6\end{array}$

$\begin{array}{llllll}\text { MeanChl } & 0.4 & 0.45 & 0.16 & -0.72 & 0.04\end{array}$

$\begin{array}{llllll}\text { MeanTemp } & 0.36 & 0.23 & 0.65 & 0.27 & 0.23\end{array}$ 
Appendix 2. Proportion of households surveyed and total estimated number of households in each community.

\begin{tabular}{|c|c|c|}
\hline Village & $\begin{array}{c}\text { Estimated number of } \\
\text { households }\end{array}$ & $\begin{array}{c}\text { Number of households } \\
\text { interviewed }\end{array}$ \\
\hline Amparamilay & 16 & 16 \\
\hline Amparoha & 30 & 30 \\
\hline Andravorogna & 23 & 23 \\
\hline Anjiabe & 188 & 50 \\
\hline Antafiambotry & 215 & 50 \\
\hline Marimbe & 25 & 25 \\
\hline Marotogny & 111 & 40 \\
\hline Nosy Iranja & 105 & 40 \\
\hline Ratapenjke & 33 & 30 \\
\hline Sakatia & 290 & 50 \\
\hline & Total & 354 \\
\hline
\end{tabular}


Appendix 3. Comparison of all the nested models to determine the best combination of human variables to explain fish biomass. The two first components (Env1 and Env2) of the Principal Component Analysis (PCA) performed with habitat and environmental variables, human population size provided initial model M0. AICc and Likelihood Ratio (LR) test performed against nested reference (ref) model determined the best combination of human variables. The best model (M3B) combined management, travel time from market and travel time from community in interaction with management.

\begin{tabular}{|l|l|l|l|}
\hline Model & Covariates & Interaction & AICc \\
\hline M0 (ref) & Env1 + Env2 + Population & $/$ & \\
\hline M1 & Env1 + Env2 + Population + Management & $/$ & \\
\hline & & $/$ & 18.0 \\
\hline M1 (ref) & Env1 + Env2 + Population + Management & ** & \\
\hline M2 & Env1 + Env2 + Population + Management + Market + Village & $/$ & 18.4 \\
\hline & & 16.3 \\
\hline M2 (ref) & Env1 + Env2 + Population + Management + Market + Village & $/$ & \\
\hline M3A & Env1 + Env2 + Population + Management + Market + Village & Management * Market & 21.0 \\
\hline M3B & Env1 + Env2 + Population + Management + Market + Village & Management * Village & 14.9 \\
\hline
\end{tabular}


Appendix 4. Correlogram showing correlations between the ten socioeconomic indicators of coastal communities and market access.

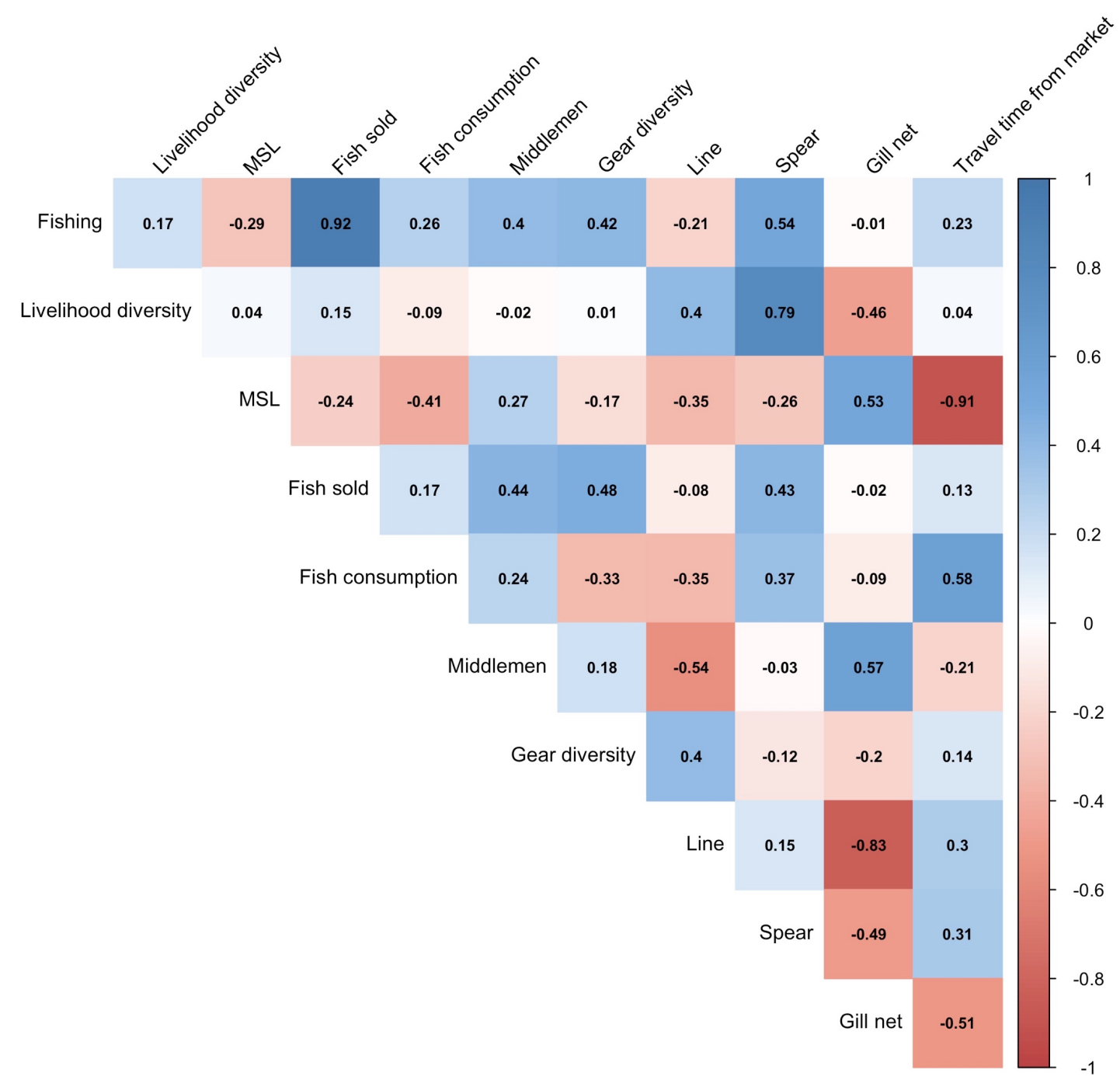


Appendix 5. Scores ( $\cos 2)$ of (a) each variable and (b) community integrated in the PCA linking market access and social characteristics of coastal communities. Ten socioeconomic indicators were assessed for each of the 10 coastal communities: the mean number of gear types (Gear diversity), the proportion of fishing households who ranked gill nets (Gill net), spear (Spear) and line (Line) as main gear, the proportion of households who ranked fishing as primary activity (Fishing), the mean number of livelihood activities that households are involved in (Livelihood div.), a composite index of community wealth (MSL), the proportion of households consuming fish at least once a day (Fish consumpt.), the proportion of fish sold (Fish sold) and the importance of middlemen (Middlemen) in fish selling that were related to market access (TT market). The supplementary variable (Management) was also represented. Most variables were properly represented $(\cos 2>0.4)$ by the two first components $(\mathrm{PC} 1$ and PC2) except fish consumption, livelihood and gear diversity. Six communities were properly represented $(\cos 2>0.4$, in bold) by the two first components (PC1 and $\mathrm{PC} 2)$.
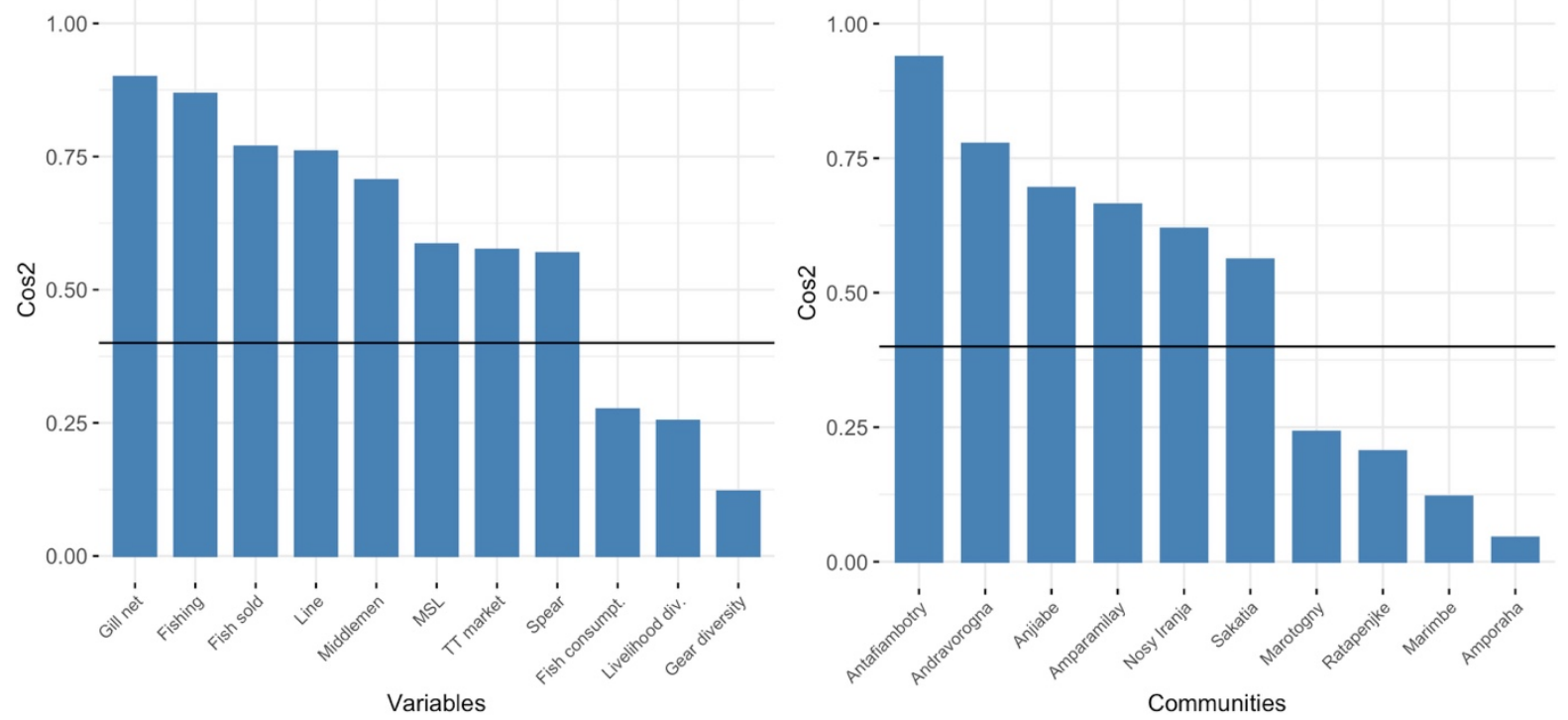
Appendix 6. Associations between market proximity and selling fish catches. We looked at the relationship between the preferred buyer: own community, middlemen from other community or local market and the proportion of fish sold. All communities sold a high proportion of their catches $(>71 \%)$ but communities regularly sold on average $90 \%$ (range: $81-93$ ) of fish catch when middlemen were the only buyer, $78 \%$ (range: $78-79$ ) to both middlemen and market and $71 \%$ to their own community when no external buyer was present.

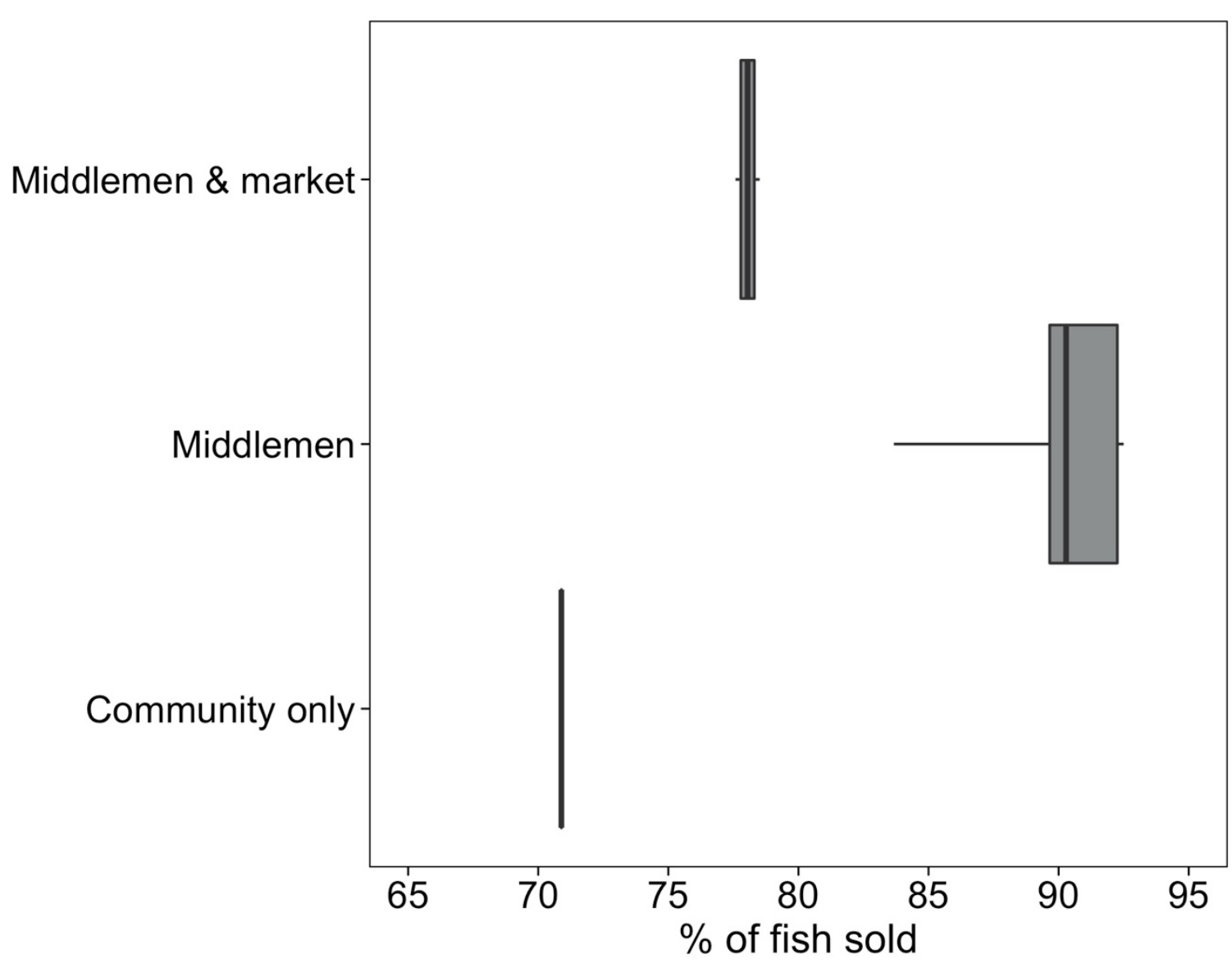

